\title{
ASPECTOS GEOLÓGICOS, HISTÓRICOS E ESTADO DE CONSERVAÇÃO DAS FORTIFICAÇÕES DA BAIXADA SANTISTA, LITORAL PAULISTA
}

\author{
Vanessa Costa MUCIVUNA
}

Eliane Aparecida DEL LAMA

Maria da Glória Motta GARCIA

\begin{abstract}
RESUMO
No Brasil, as fortificações militares foram construídas em locais estratégicos com a finalidade de defesa do território. Atualmente, muitas delas encontram-se tombadas como representantes do período colonial e são utilizadas com fins turísticos. Este trabalho tem por objetivo identificar as rochas utilizadas nas construções das fortificações militares construídas entre os séculos XVI e XX na Baixada Santista nos municípios de Bertioga, Guarujá e Praia Grande (SP) e inferir sua provável proveniência. A identificação do tipo de material usado nessas construções permite compreender a história, a cultura, a evolução técnica e a geodiversidade da época. Buscou-se ainda apresentar um histórico dessas fortificações e avaliar seu estado de conservação atual, para poder subsidiar as ações de preservação e manutenção do patrimônio cultural pétreo. As fortificações foram edificadas com granitos e gnaisses que afloram na região. Apesar de algumas serem tombadas pelo Instituto do Patrimônio Histórico e Artístico Nacional (IPHAN) e terem uso voltado à visitação turística, parte delas está deteriorada e necessita-se de indispensáveis reparos para que esse patrimônio, representativo de uma época da defesa do território paulista, seja conservado e preservado.
\end{abstract}

Palavras-chave: Fortificações; conservação; monumentos pétreos; patrimônio histórico; Baixada Santista.

\section{ABSTRACT}

GEOLOGICAL AND HISTORICAL ASPECTS AND CONSERVATION STATUS OF THE FORTIFICATIONS OF THE SANTOS REGION ON THE COAST

OF SÃO PAULO STATE. Military fortifications were built at strategic locations in Brazil for the purpose of defending the territory. Currently, many of them are protected by law as representatives of the colonial period and are used for tourist purposes. The aim of this study is to identify the types of stones used in the construction of military fortifications built between sixteenth and twentieth centuries on the coast of São Paulo State within the municipalities of Bertioga, Guarujá and Praia Grande and infer the probable origin of these stones. Identification of the type of material used in these constructions allows a better understanding of the history, culture, technical and geodiversity at the time of their construction. The evaluation of their condition and current use is intended to support actions to which the fortifications may be submitted in order to preserve and maintain the cultural heritage in stone. The fortifications were constructed mainly with granites and gneisses that crop out in the region. Although some of them are listed by the National Institute for Historical and Artistic Heritage (IPHAN) and are the focus of tourism, some of them are deteriorated and require repair in order to conserve and preserve these fortifications, which represent a period in the defense of the State of São Paulo.

Keywords: Fortifications; conservation; stone monuments; historic heritage; Baixada Santista. 


\section{INTRODUÇÃO}

A história das fortificações muitas vezes se confunde com a história do desenvolvimento de uma nação, pois muitas constituem marcos da criação de cidades e tinham por objetivo a proteção do território.

A construção das fortificações ocorria, em diversos países do mundo, de duas formas principais: a paliçada, de caráter temporário e feita com materiais pouco resistentes, e as fortificações permanentes, construídas com materiais resistentes para durarem longos períodos. Estas últimas, geralmente, eram edificadas essencialmente com blocos de pedras unidos com argamassa de cal. Os materiais para a construção eram obtidos nas proximidades da obra, quando disponíveis, para se evitar o trabalho e o custo com o transporte.

A partir da análise do material utilizado na construção é possível identificar a geodiversidade local e a evolução econômica, arquitetônica e da construção civil da época.

Os materiais pétreos utilizados nas construções das fortificações, apesar de sua resistência, também estão sujeitos à deterioração frente aos processos intempéricos, sejam de ordem física ou química. Por conta disso, eles podem ser pouco a pouco deteriorados, causando risco à integridade das edificações e, em última instância, à história que representam. A avaliação do estado atual do material pétreo também visa diagnosticar seus danos e, assim, subsidiar tratamentos de restauro porventura necessários.

A partir de meados do século XX a arquitetura militar perde a função de fortificar o território para fins de defesa, devido ao uso de mísseis balísticos de longo alcance e alta precisão. Atualmente, a maior parte das fortificações no Brasil deixou a função de defesa do território, permanecendo, entretanto, como remanescentes do patrimônio cultural e são utilizadas com função turística e educativa. No Brasil, muitas fortificações são atrações turísticas, tais como, Forte de Santo Antônio da Barra (Salvador - BA), Forte Orange (Itamaracá $\mathrm{PE}$ ), Forte das Cinco Pontas (Recife - PE), Forte dos Reis Magos (Natal - RN), Forte de Copacabana (Rio de Janeiro - RJ), Fortaleza de Santa Cruz da Barra (Niterói - RJ), Forte de São José da Ponta Grossa (Florianópolis - SC) e Forte do Castelo (Belém - PA).

A Baixada Santista é uma região que recebe todos os anos milhares de pessoas para o turismo de balneário, porém o potencial turístico do seu pa- trimônio cultural, em especial aquele relacionado à arquitetura militar presente nas fortificações, é pouco explorado.

Dentre as fortificações ainda existentes na Baixada Santista, muitas foram incluídas no projeto "Circuito dos Fortes", concebido para resgatar e divulgar o patrimônio histórico-militar da região. O circuito é representado por três "cortinas duplas de fortificações", que começaram a ser construídas durante o período colonial com o objetivo de defender as vilas de Santos, São Vicente e do porto de Santos (AGEM 2005). As "cortinas de dupla fortificações" constituem construções edificadas em lados opostos de um curso d'água, com a finalidade de cruzarem fogos e impedir a invasão por vias aquáticas. O circuito completo é composto por oito pontos ( 6 fortificações que são objetos de estudo neste artigo, e mais o Museu da Pesca e a Casa do Trem Bélico), de forma que ao completá-lo, o visitante conhece um pouco da história da Baixada Santista e, consequentemente, do Brasil.

Este artigo tem como objetivo caracterizar as diferentes rochas utilizadas na construção de fortificações remanescentes da Baixada Santista nos municípios de Bertioga, Guarujá e Praia Grande, litoral central do estado de São Paulo, bem como identificar a proveniência desses materiais. Além disso, avaliou-se o estado de conservação atual dessas fortificações, mediante levantamentos históricos prévios.

\section{MÉTODOS}

Levantamento bibliográfico dos aspectos geológicos e históricos, em conjunto com trabalhos de campo, foram realizados para caracterizar os tipos de rochas utilizados nas construções e registrar o seu estado de conservação.

A análise e interpretação da proveniência dos materiais usados nas edificações baseou-se na comparação com o Mapa Geológico do Estado de São Paulo, escala 1:750.000 (PERROTTA et al. 2005). A procedência dos materiais não pôde ser definida com exatidão, devido à falta de registros históricos. Nestes casos, trabalhos de campo foram realizados com a finalidade de comparar as rochas utilizadas nas fortificações com as das unidades geológicas da região com características similares.

Para fins de conceituação, o termo pedra comumente utilizado nos trabalhos da área de conservação do patrimônio - está relacionado com os materiais pétreos do contexto da obra e trabalhados 
pelo Homem, ou seja, os materiais utilizados nas construções das fortificações. Já o termo rocha é utilizado quando envolver as propriedades petrográficas e suas relações com o contexto geológico.

Nesta análise considera-se o estado de conservação de cada uma das fortificações estudadas no que se refere ao seu uso atual, parcela de originalidade, estado de conservação e restauro e a forma como é feita sua divulgação ao público que o visita, ou seja, o turista.

\section{AS FORTIFICAÇÕES NO TERRITÓRIO BRASILEIRO}

Entende-se por fortificação toda e qualquer obra de defesa militar, seja ela temporária ou permanente. Como exemplo de fortificação temporária tem-se o entrincheiramento, destinado a satisfazer as necessidades táticas que podem ocorrer numa campana, permitindo colocar a tropa ao abrigo e sob proteção. As fortificações permanentes, por sua vez, possuem diversas denominações: o fortim consiste num pequeno forte, o forte é a instalação de uma ou mais bateria de artilharia posicionada numa mesma obra e a fortaleza é uma estrutura composta por duas ou mais baterias de artilharia distribuídas em obras independentes (BARRETO 1958).

O processo de fortificação do território brasileiro não difere da forma como ocorreu em outros países do mundo. No Brasil, a construção de fortificações militares esteve relacionada à defesa do litoral e teve por objetivo minimizar os riscos de exposição da costa a assaltos de piratas ingleses, franceses e holandeses que, à época, tentavam a posse das regiões ainda não efetivamente ocupadas por povoações (MORI et al. 2003). O primeiro registro de construção de uma fortificação em terras brasileiras data de 1532, com a chegada de Martim Afonso de Souza, na Barra de Bertioga, onde ele ordenou edificar uma paliçada de madeira para defender a entrada do canal de Bertioga (BARRETO 1958).

De acordo com KLINTOWITZ (1983) a construção das fortificações era realizada com as rochas extraídas e conduzidas uma a uma até o local onde o solo tinha sido escavado. Com relação à tecnologia adotada, os fortes brasileiros utilizaram de uma concepção ultrapassada de guerra e de conquista, pois na Europa já existiam técnicas mais avançadas para a pirobalística.
Para MORI et al. (2003), até o ano de 1580 o sistema defensivo português implantado no Brasil era incipiente, pois não havia muitos valores para defender a não ser as poucas povoações existentes. Somente durante o domínio da Espanha sobre Portugal que se implantaram os grandes sistemas de fortificação, devido à ameaça da invasão holandesa. Na época os italianos eram considerados os maiores especialistas em fortificações; dessa forma, os espanhóis adotaram o modelo italiano de construção a partir do século XVII. Assim, as características medievais das fortificações brasileiras foram abandonadas, tendo sido privilegiadas as construções baixas, as quais conseguiam resistir melhor aos impactos dos projéteis (NAKAMUTA 2009).

Um exemplo de fortificação no Brasil feita pelos italianos é o Forte dos Reis Magos em Natal $(\mathrm{RN})$, projetado pelo arquiteto Giovanni Antonelli no século XVI. Em sua construção utilizaram-se os beachrocks, comuns no local, além do Calcário Lioz - trazido de Portugal como lastro nos navios e usado no interior do forte (LICCARDO 2010).

No Brasil, desde os primeiros anos do descobrimento até meados do século $\mathrm{XX}$, foram construídas aproximadamente 300 fortificações, tanto pelos colonizadores quanto pelos invasores (portugueses, holandeses, franceses, ingleses, espanhóis e brasileiros), sendo que as de menor importância resistiram por pouco tempo (BARRETO 1958).

CASTRO (2009), com base nos trabalhos de Rego Monteiro, elaborou um mapa com a distribuição aproximada das fortificações existentes no Brasil em 1829 (Figura 1). Essa distribuição apresenta algumas deficiências de confiabilidade na fonte dos dados; algumas fortificações ainda não tinham sido construídas naquela data, enquanto outras estão situadas em território uruguaio (quatro precisamente). Porém, a partir dessa distribuição é possível visualizar como as fortificações faziam a cobertura de defesa do território brasileiro durante aquele período, concentradas principalmente no litoral, nos grandes rios e nas fronteiras terrestres.

Muitas dessas fortificações foram tombadas pelo Instituto do Patrimônio Histórico e Artístico Nacional (IPHAN) ao longo dos anos, porém, em alguns casos, restaram apenas suas ruínas. Atualmente a maior parte das fortificações perdeu a função de defesa do território e são utilizadas para fins turísticos e educativos, após diversos serviços de restauro e conservação. 


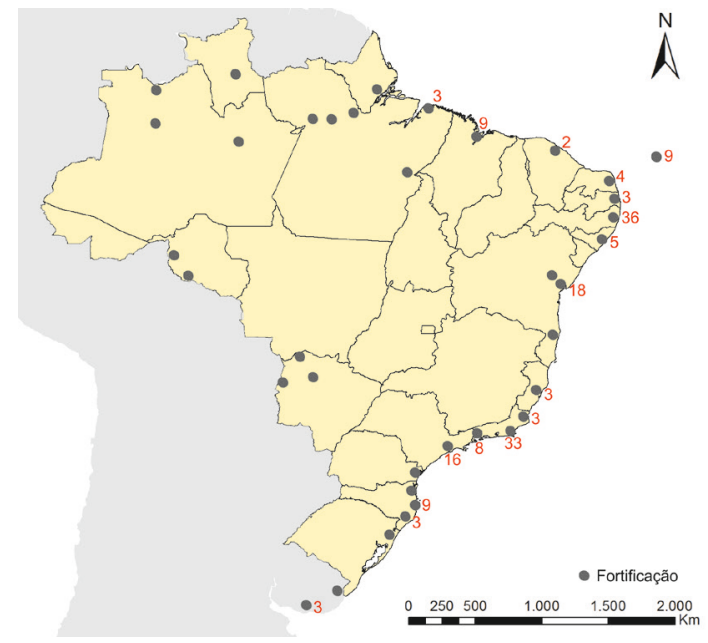

FIGURA 1 - Localização das fortificações existentes no Brasil em 1829. Os números indicam a quantidade de fortificações próximas do local. Modificado de CASTRO (2009).

\section{AS FORTIFICAÇÕES DO LITORAL PAULISTA}

BARRETO (1958) mostra que no estado de São Paulo existiram dezesseis fortificações concentradas no litoral paulista. A Fortaleza de Santo Amaro da Barra Grande e o Fortim da Praia do Góes (Guarujá/SP) são consideradas pelo autor como fortificação única. No entanto, para caracterizar o histórico e o tipo de material construtivo, esse artigo trata as duas fortificações separadamente. O fato do autor não incluir em seu estudo o Forte da Vila de São Sebastião, no município homônimo - como proposto por MORI et al. (2003) - mostra que, na verdade, o litoral paulista possuía dezoito fortificações.

De acordo com CAMARGO (2002), as fortificações construídas no litoral do estado de São Paulo (Figura 2) concentraram-se em três subsistemas principais: Cananeia-Iguape (Figura 2A), San-

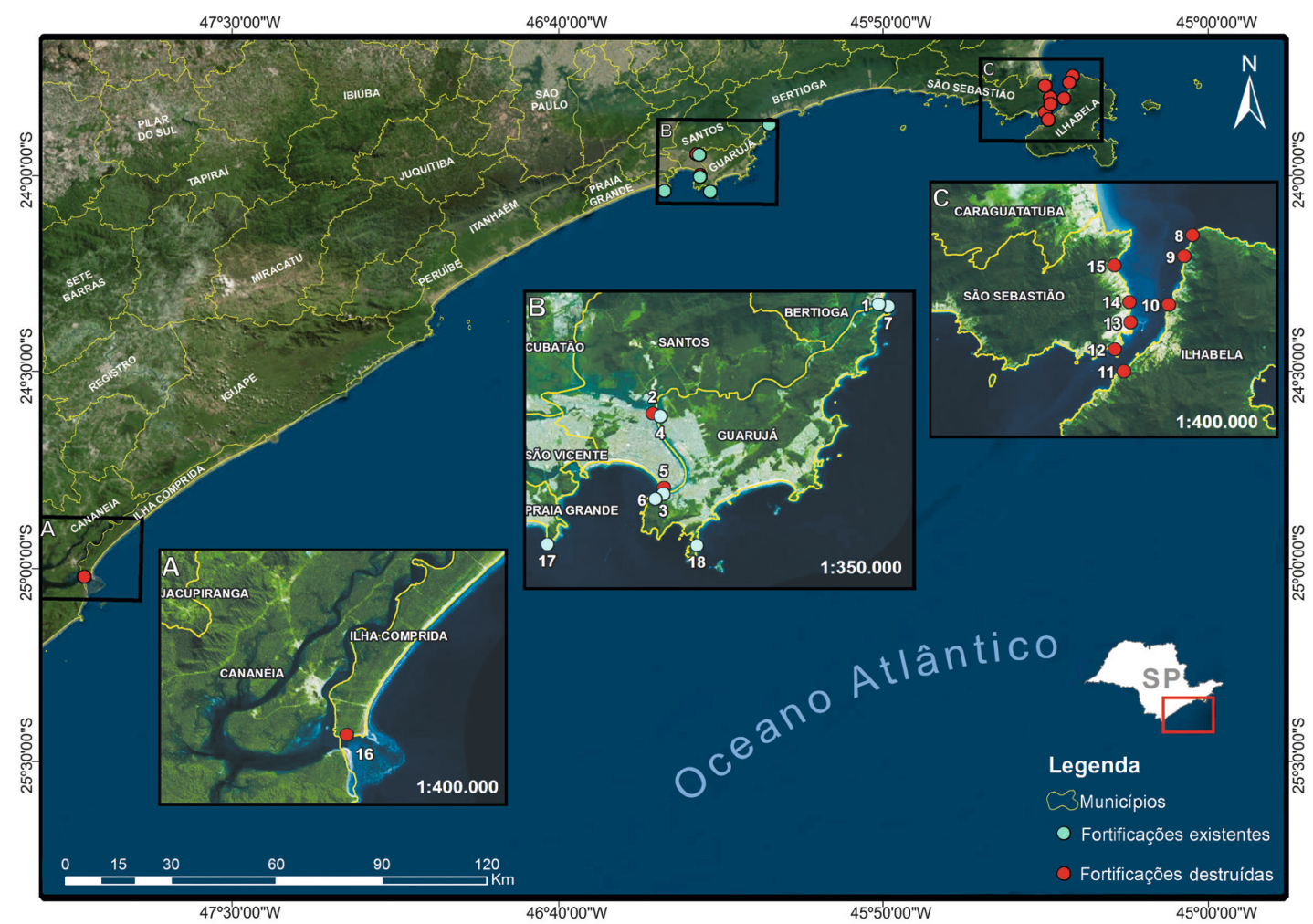

FIGURA 2 - Localização das fortificações do litoral paulista. A-Subsistema Cananeia-Iguape. B- Subsistema Santos. C- Subsistema São Sebastião-Ilhabela. 1 - Forte São João. 2 - Forte de Santos. 3 - Fortaleza de Santo Amaro da Barra Grande. 4 - Fortaleza de Vera Cruz de Itapema. 5 - Forte da Estacada. 6 - Fortim da Praia do Góes. 7 - Forte São Luiz. 8 - Forte da Ponta das Canas. 9 - Forte do Rabo Azêdo. 10 - Forte da Vila Bela. 11 - Forte da Feiticeira. 12 - Forte do Araçá. 13 - Forte da Vila de São Sebastião. 14 - Forte de Santa Cruz. 15 Forte de Sepetuba. 16 - Forte de Cananeia. 17 - Fortaleza de Itaipu. 18 - Forte dos Andradas. Fontes: Landsat ETM+ RGB 321. Dados das fortificações destruídas extraídos de CAMARGO (2002) e MORI et al. (2003). 
tos (Figura 2B) e São Sebastião-Ilhabela (Figura 2C). Atualmente, restam apenas sete fortificações, localizadas na Baixada Santista (Figura 2B). As onze fortificações não preservadas localizavam-se em Ilha Comprida, Santos, Ilhabela e São Sebastião (Figuras 2A, B e C). Elas foram destruídas, seja por conta do intemperismo, negligência das administrações, para dar lugar ao desenvolvimento da cidade ou, ainda, pela falta de consciência da necessidade de preservação da memória nacional, tal como ocorreu com diversas outras fortificações no território brasileiro (OLIVEIRA 2004).

Dentre as fortificações ainda existentes no litoral do estado de São Paulo, seis integram o Circuito dos Fortes desde 2004, com exceção do Fortim da Praia do Góes: Forte São João - Bertioga, Fortaleza de Santo Amaro da Barra Grande - Guarujá, Fortaleza de Vera Cruz de Itapema - Guarujá, Forte São Luiz - Guarujá, Fortaleza de Itaipu - Praia Grande e Forte dos Andradas - Guarujá.

A maior parte das fortificações que desapareceu (Tabela 1, Figura 2) foi construída com o objetivo de criar um sistema de defesa ao longo do Canal de São Sebastião. Elas foram edificadas a base de madeira e terra, com projetos desenhados em planta semicircular, semelhante às fortificações ultrapassadas do Forte de Monserrate (destruído), Fortaleza de Vera Cruz de Itapema e Fortim da Praia do Góes (MORI et al. 2003). Por conta da chegada da ferrovia em Santos e o desenvolvimento do seu porto, o porto de São Sebastião acabou perdendo sua importância. Além disso, os engenhos de açúcar do litoral norte entraram em decadência, fazendo com que as fortificações construídas nesse local fossem abandonadas (MORI et al. 2003).

OLIVEIRA (2004) aponta que restam apenas algumas memórias em icnografias e plantas cadastrais das fortificações que desapareceram no território brasileiro, sendo que vários desenhos de projetos se perderam ou foram extraviados.

\section{CONTEXTO GEOLÓGICO DA BAIXADA SANTISTA}

A área de estudo está inserida na Faixa Ribeira, orógeno da Província Mantiqueira (ALMEIDA et al. 1977, 1981) de idade neoproterozoica, formada durante o Ciclo Brasiliano Pan-Africano.

O Orógeno Ribeira (HEILBRON et al. 2004) é uma faixa com mais de $1.000 \mathrm{~km}$ ao longo da costa brasileira, cuja origem está relacionada ao fechamento do Oceano Adamastor e à colisão entre os crátons São Francisco-Congo Ocidental durante o ciclo tectônico Brasiliano Pan-Africano. Esses processos colisionais geraram um trend estrutural NE-SW que é responsável por parte do controle estrutural da região.

PERROTTA et al. (2005) descrevem que a área é composta pelas unidades tectono-estratigráficas do Terreno Serra do Mar e pelas Coberturas Sedimentares Cenozoicas (Figura 3). O embasamento da região é formado pelas unidades litoestratigráficas do Complexo Costeiro (Gnaisses Bandados, Gnaisses Peraluminosos, Ortognáissica e Granito gnáissica migmatítica), do magmatismo pós-colisional tardio (Granito Pai Matias, Granito Taiaçupeba, Granito Guarujá-Santos, e Granito Morrão) (AZEVEDO SOBRINHO et al. 2011) e pelos sedimentos cenozoicos (Formação Cananeia, Coberturas Detríticas Indiferenciadas, Coberturas Litorâneas Indiferenciadas e pelos Depósitos Aluvionares), além da Zona de Cisalhamento do Bairro Alto, estrutura regional com orientação NE-SW (MAFFRA 2000).

As fortificações estudadas localizam-se sobre as unidades litoestratigráficas do Complexo Costeiro (Gnaisses Bandados e Gnaisses Peraluminosos), Granito Guarujá-Santos e Depósitos Litorâneos Indiferenciados (PERROTTA et al. 2005).

A Unidade de Gnaisses Bandados foi descrita no município de Mongaguá, como um gnaisse migmatítico de composição monzogranítica e estrutura gnáissica, caracterizada por bandas irregulares félsicas, quartzo-feldspáticas, intercaladas com bandas máficas. É constituída por quartzo, microclínio, oligoclásio, hornblenda e biotita. Datações U-Pb em zircões indicam idade de $612 \mathrm{Ma}$ (PASSARELLI 2001).

As rochas da Unidade dos Gnaisses Peraluminosos foram descritas no município de São Sebastião como paragnaisses heterogêneos, com predomínio de gnaisses kinzigíticos, rochas calcissilicáticas e anfibolitos. Os gnaisses são constituídos por plagioclásio, quartzo e biotita. Determinações de U-Pb obtidas no SHRIMP, realizadas nos gnaisses kinzigíticos, indicam idade de $571 \pm 10$ Ma para este metamorfismo (DIAS NETO 2001).

O magmatismo pós-colisional tardio (AZEVEDO SOBRINHO et al. 2011) está representado pelo Granito Guarujá-Santos. Este granito ocorre como pequenos corpos que afloram na região de Bertioga, Guarujá e Santos entremeados pelos sedimentos cenozoicos. Trata-se de uma rocha homogênea, classificada como biotita granito porfirítico, com matriz de granulação média a grossa 
TABELA 1 - Fortificações destruídas no litoral do estado de São Paulo. Fontes: SOUZA (1885), BARRETO (1958), CAMARGO (2002), MORI et al. (2003).

\begin{tabular}{|c|c|c|c|c|c|}
\hline $\begin{array}{c}\text { Nome da } \\
\text { fortificação }\end{array}$ & Localização & $\begin{array}{l}\text { Data de início } \\
\text { da construção }\end{array}$ & $\begin{array}{c}\text { Responsável } \\
\text { pela construção }\end{array}$ & $\begin{array}{l}\text { Construção em } \\
\text { cortina dupla de } \\
\text { fortificação }\end{array}$ & $\begin{array}{c}\text { Outras } \\
\text { informações }\end{array}$ \\
\hline $\begin{array}{l}\text { Forte de Santos, } \\
\text { Forte da Villa ou } \\
\text { Forte Monserrate }\end{array}$ & $\begin{array}{c}\text { Próximo à cidade } \\
\text { de Santos }\end{array}$ & $\begin{array}{c}1543 \text { e } \\
\text { reconstruído em } \\
1770\end{array}$ & Braz Cubas & $\begin{array}{l}\text { Fortaleza de Vera } \\
\text { Cruz Itapema, } \\
\text { município de } \\
\text { Guarujá }\end{array}$ & $\begin{array}{c}\text { Em } 1905 \text { suas ruínas } \\
\text { desapareceram por } \\
\text { conta da ampliação } \\
\text { do porto de Santos. }\end{array}$ \\
\hline $\begin{array}{l}\text { Forte da Estacada, } \\
\text { Forte do Crasto ou } \\
\quad \text { Forte Augusto }\end{array}$ & $\begin{array}{c}\text { Bairro da } \\
\text { Ponta da Praia, } \\
\text { município de } \\
\text { Santos }\end{array}$ & $\begin{array}{c}1734 \text { e reformado } \\
\text { em } 1770\end{array}$ & $\begin{array}{c}\text { João de Castro } \\
\text { Oliveira }\end{array}$ & $\begin{array}{l}\text { Fortaleza de Santo } \\
\text { Amaro da Barra } \\
\text { Grande, município } \\
\text { de Guarujá }\end{array}$ & $\begin{array}{c}\text { Em } 1861 \text { já estava } \\
\text { desativado e foi } \\
\text { demolido no início } \\
\text { do século XX. }\end{array}$ \\
\hline $\begin{array}{l}\text { Forte da Ponta das } \\
\text { Canas }\end{array}$ & $\begin{array}{c}\text { Ponta das } \\
\text { Canas, Ilha de } \\
\text { São Sebastião, } \\
\text { município de } \\
\text { Ilhabela }\end{array}$ & 1800 & $\begin{array}{c}\text { Governador } \\
\text { militar } \\
\text { Maximiliano } \\
\text { Augusto Penido }\end{array}$ & -- & $\begin{array}{l}\text { Foi construído para } \\
\text { proteger a fábrica de } \\
\text { óleo de baleia, mas } \\
\text { não foi concluído. }\end{array}$ \\
\hline Forte do Araçá & $\begin{array}{l}\text { Morro ao sul da } \\
\text { Vila da Ponta do } \\
\text { Araçá, município } \\
\text { de São Sebastião }\end{array}$ & 1820 & $\begin{array}{l}\text { Governador } \\
\text { militar } \\
\text { Maximiliano } \\
\text { Augusto Penido }\end{array}$ & $\begin{array}{c}\text { Forte da Feiticeira, } \\
\text { município de } \\
\text { Ilhabela }\end{array}$ & $\begin{array}{l}\text { Nada resta desta } \\
\text { fortificação. }\end{array}$ \\
\hline Forte da Feiticeira & $\begin{array}{c}\text { Praia da } \\
\text { Feiticeira, Ilha } \\
\text { de São Sebastião, } \\
\text { município de } \\
\text { Ilhabela. }\end{array}$ & 1820 & $\begin{array}{c}\text { Governador } \\
\text { militar } \\
\text { Maximiliano } \\
\text { Augusto Penido }\end{array}$ & $\begin{array}{l}\text { Forte do Araçá, } \\
\text { município de São } \\
\text { Sebastião }\end{array}$ & $\begin{array}{c}\text { Não há nem os } \\
\text { vestígios. }\end{array}$ \\
\hline $\begin{array}{l}\text { Forte do Rabo } \\
\text { Azêdo }\end{array}$ & $\begin{array}{l}\text { Norte da Ilha de } \\
\text { São Sebastião, } \\
\text { município de } \\
\text { Ilhabela }\end{array}$ & 1820 & $\begin{array}{l}\text { Governador } \\
\text { militar } \\
\text { Maximiliano } \\
\text { Augusto Penido }\end{array}$ & $\begin{array}{l}\text { Forte de Sepetuba } \\
\text { e Forte de Santa } \\
\text { Cruz, município } \\
\text { de São Sebastião }\end{array}$ & $\begin{array}{l}\text { Nada resta desta } \\
\text { fortificação. }\end{array}$ \\
\hline $\begin{array}{l}\text { Forte de Santa } \\
\qquad \text { Cruz }\end{array}$ & $\begin{array}{l}\text { Ao sul do Forte } \\
\text { de Sepetuba, } \\
\text { município de São } \\
\text { Sebastião }\end{array}$ & 1820 & $\begin{array}{c}\text { Governador } \\
\text { militar } \\
\text { Maximiliano } \\
\text { Augusto Penido }\end{array}$ & $\begin{array}{c}\text { Forte do Rabo } \\
\text { Azêdo, município } \\
\text { de Ilhabela }\end{array}$ & $\begin{array}{l}\text { Nada resta desta } \\
\text { fortificação. }\end{array}$ \\
\hline $\begin{array}{c}\text { Forte de Sepetuba } \\
\text { ou Forte de } \\
\text { Sapituba }\end{array}$ & $\begin{array}{c}\text { Ao norte do canal, } \\
\text { município de São } \\
\text { Sebastião }\end{array}$ & 1820 & $\begin{array}{c}\text { Governador } \\
\text { militar } \\
\text { Maximiliano } \\
\text { Augusto Penido }\end{array}$ & $\begin{array}{l}\text { Forte do Rabo } \\
\text { Azêdo, município } \\
\text { de Ilhabela }\end{array}$ & $\begin{array}{l}\text { Não há nem os } \\
\text { vestígios. }\end{array}$ \\
\hline Forte da Vila Bela & $\begin{array}{c}\text { Numa ilhota } \\
\text { situada entre o } \\
\text { continente e a Ilha } \\
\text { de São Sebastião }\end{array}$ & 1820 & $\begin{array}{c}\text { Governador } \\
\text { militar } \\
\text { Maximiliano } \\
\text { Augusto Penido }\end{array}$ & $\begin{array}{l}\text { Forte da Vila de } \\
\text { São Sebastião, } \\
\text { município } \\
\text { homônimo }\end{array}$ & $\begin{array}{l}\text { Abandonado, } \\
\text { atualmente nada } \\
\text { resta. }\end{array}$ \\
\hline $\begin{array}{l}\text { Forte da Vila de } \\
\text { São Sebastião }\end{array}$ & $\begin{array}{c}\text { Na vila, } \\
\text { município de São } \\
\text { Sebastião }\end{array}$ & 1820 & $\begin{array}{c}\text { Governador } \\
\text { militar } \\
\text { Maximiliano } \\
\text { Augusto Penido }\end{array}$ & $\begin{array}{c}\text { Forte da Vila Bela, } \\
\text { município de } \\
\text { Ilhabela }\end{array}$ & $\begin{array}{l}\text { Não há nem os } \\
\text { vestígios. }\end{array}$ \\
\hline $\begin{array}{c}\text { Forte de Cananeia } \\
\text { ou Forte da } \\
\text { Trincheira }\end{array}$ & $\begin{array}{c}\text { Ponta da } \\
\text { Trincheira, } \\
\text { margem esquerda } \\
\text { da Barra de } \\
\text { Cananeia, } \\
\text { município de Ilha } \\
\text { Comprida }\end{array}$ & $\begin{array}{c}1824 \mathrm{e} \\
\text { reedificado em } \\
1839\end{array}$ & $\begin{array}{l}\text { Tenente Antonio } \\
\text { Mariano dos } \\
\text { Santos }\end{array}$ & -- & $\begin{array}{l}\text { Destruído pela } \\
\text { erosão marinha. }\end{array}$ \\
\hline
\end{tabular}




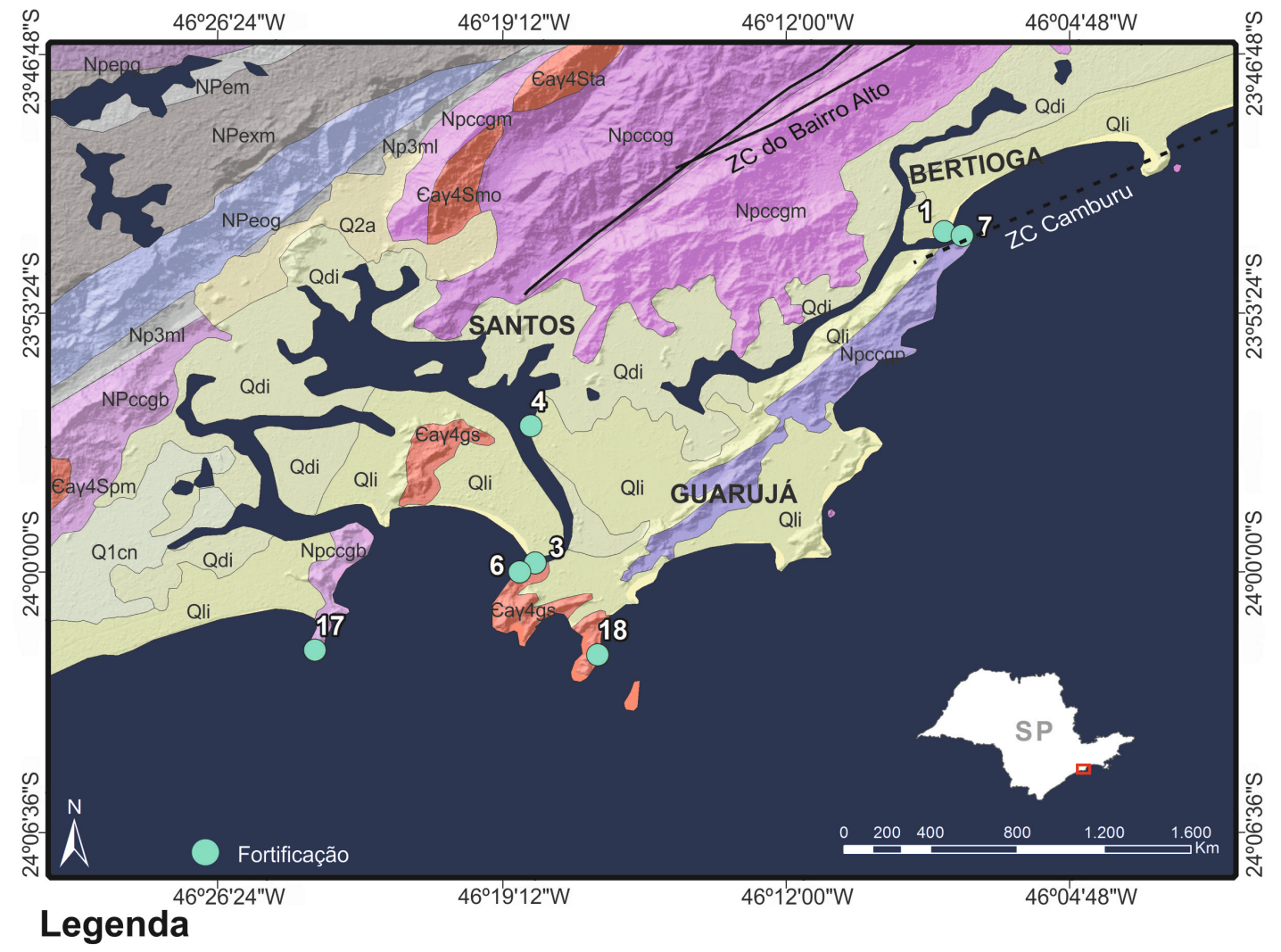

CENOZOICO

Q2a Depósitos Aluvionares (areia, areia quartzosa, cascalheira, silte, argila e, localmente, turfa).

Q1cn Formação Cananeia (sedimento arenoso fino; na base ocorrem níveis de minerais pesados e intercalações argilosas, estratificações ondulada e cruzada de baixo ângulo, intensa bioturbação e estrutura de sobrecarga; no topo ocorrem estratificações plano-paralela e greta de contração)

Qli Depósitos Litorâneos Indiferenciados (areia, silte e argila).

Qdi Coberturas Detríticas Indiferenciadas (areia, silte, argila e cascalho inconsolidados).

\section{NEOPROTEROZOICO-EOPALEOZOICO}

Eay4Smo Granito Morrão

(biotita-muscovita granitos (localmente granodioritos) leucocráticos, cinza claros, levemente foliados, de granulação Granito Pai Matias fina a média e localmente grossa. Ocorrem também fácies porfiriticas foliadas com matriz inequigranular média Granito Taiaçupeba (e megacristais idiomórficos ou ovalados de feldspato orientados).

Granito Guarujá-Santos(biotita granito foliado, porfirítico, com matriz de granulação média-grossa cinza e enclaves quartzo dioríticos frequentes (Santos et al., 1977). Em Santos ocorre fácies tardia de granito equigranular, maciço, de granulação fina a média, cor bege ou rosa e textura hipidiomórfica cortada por veios aplíticos).

\section{NEOPROTEROZOICO}

$\mathrm{Np} 3 \mathrm{ml}$ Rochas Miloníticas (granitoide e, localmente, rocha metassedimentar milonítica, protomilonítica e ultramilonítica, biotita gnaisse milonítico, biotita granito porfiroclástico).

Npccog Complexo Costeiro, Unidade Ortognáissica (ortognaisse migmatítico cálcio-alcalino, (hornblenda)-biotita granitoide gnáissico porfiroide e augen gnaisse).

NPccgp Complexo Costeiro, Unidade de Gnaisses Peraluminosos (gnaisse kinzigítico com núcleos antigos com restitos biotíticos, rocha calcissilicática e anfibolito).

Npccgm Complexo Costeiro, Unidade Granito-gnáissica-migmatítica (hornblenda-biotita gnaisse granitoide porfiroide e augen gnaisse).

Npcogb Complexo Costeiro, Unidade de Gnaisses Bandados (gnaisse migmatítico de composição monzogranítica, com bandas quartzo-feldspáticas e máficas).

Npem Complexo Embu, Unidade Milonítica (granada-biotita-muscovita xisto milonítico com intercalações de biotita quartzito, biotita xisto, sericita filito e metarcóseo fino).

NPepg Complexo Embu, Unidade Paragnáissica (muscovita-granada-sillimanita-biotita gnaisse migmatítico, biotita gnaisse tonalítico a granodiorítico; xisto gnaissoide e biotita gnaisse quartzoso).

NPexm Complexo Embu, Unidade de Xistos Localmente Migmatíticos (muscovita-biotita-quartzo xisto com cianita, estaurolita, granada sillimanita e quartzo xisto com muscovita, biotita, granada e plagioclásio alternados ritmicamente, intercalações de rocha calcissilicática,

NPeog Complexo Embu, Unidade Ortognáissica (biotita gnaisse homogêneo, granodiorítico a tonalítico).

FIGURA 3 - Contexto geológico e localização das fortificações estudadas (Simplificado de PERROTTA et al. 2005). 1 - Forte São João. 3 - Fortaleza de Santo Amaro da Barra Grande. 4 - Fortaleza de Vera Cruz de Itapema. 6 - Fortim da Praia do Góes. 7 - Forte São Luiz. 17 - Fortaleza de Itaipu. 18 - Forte dos Andradas. 
de cor cinza, com frequentes enclaves quartzo-dioríticos (SILVA et al. 1977). Idades U-Pb obtidas no SHRIMP em zircões indicam idade de cristalização de $497 \pm 7$ Ma (JANASI et al. 2015).

As coberturas sedimentares cenozoicas são representadas pelos Depósitos Litorâneos Indiferenciados, compostos por sedimentos de areia, silte e argila. São depósitos de idade holocênica, relacionados à Transgressão Santos e constituídos por sequências arenosas e argilo-arenosas de origem marinha e flúvio-lagunar (SUGUIO \& MARTIN 1978).

Em função da escala do mapa de PERROTTA et al. (2005) - 1:750.000 - a caracterização das rochas observadas nos trabalhos de campo de algumas fortificações difere da apresentada no mapa. Inexistem mapeamentos de detalhe para a área de estudo.

\section{ASPECTOS HISTÓRICOS E GEOLÓGICOS DAS FORTIFICAÇÕES DA BAIXADA SANTISTA}

As fortificações possuem diferentes tipos de construções arquitetônicas e de uso de materiais, devido aos distintos momentos históricos da construção de cada fortificação, bem como dos materiais disponíveis.

As fortificações (Figura 4) foram construídas com rochas que afloravam na própria região, em função da facilidade de transporte. Adicionalmente, os europeus conheciam e dominavam a arte da cantaria. Esta técnica foi introduzida no Brasil com a chegada de Tomé de Souza, que trouxe o mestre Luís Dias, construtor de vários fortes (MANSUR et al. 2008).

\subsection{Município de Bertioga}

\subsubsection{Forte São João}

\section{Histórico e estado de conservação}

O Forte São João está localizado na extremidade sul da praia da Enseada, no atual município de Bertioga (Figura 4A). Sua fundação data do século XVI e se localiza num ponto estratégico do território paulista, palco de inúmeros ataques indígenas contrários à colonização portuguesa. A construção foi feita pelos irmãos Braga em 1532 como um entrincheiramento, por ordem de Martim Afonso de Souza, que o denominou de São Tiago. O local sofreu ataques indígenas em 1547 e 1551, causando a destruição do baluarte e da paliçada (BARRETO 1958, TEIXEIRA 2011), por conta disso, o rei de
Portugal ordenou a construção do forte em alvenaria em 1551 e, em 1553, foi enviado um projeto arquitetônico pela coroa (MORI et al. 2003).

$\mathrm{O}$ forte foi construído com pedras unidas por argamassa à base de barro, cal de sambaqui, areia e óleo de baleia (CASTRO 2010, TEIXEIRA 2011) e, de acordo com BARRETO (1958), só foi concluído em 1710. O uso de óleo de baleia nas argamassas das construções brasileiras, apesar de estar no senso comum, é uma técnica ainda não comprovada, conforme SANTIAGO (1992) e PARDAL (1999).

$\mathrm{O}$ primeiro registro de modificação no forte é de 1751, executada pelo Governador Luís Antônio de Sá e Queiroga, com a reedificação da torre de Bertioga. Em 1769 um maremoto provocou a destruição parcial do forte. A segunda interferência ocorreu em 1817, quando o engenheiro Rufino José Felizardo e Costa executou uma grande obra nessa fortificação (MORI et al. 2003).

Em 1904, Euclides da Cunha relata que o Forte São João estava "acaçapado e em ruínas cômodos estavam mal repartidos, sem soalhos e quase sem abrigo, sob um telhado levadio que desabou em parte" (CUNHA 1904, p. 677). Naquela época o forte era utilizado como um dos postos da linha costeira do telégrafo nacional, sendo esta a principal razão por não ter sido deixado ao total abandono.

Em 1920 o forte foi restaurado como monumento histórico e, em 1940, foi tombado pelo Serviço do Patrimônio Histórico e Artístico Nacional - SPHAN. Dois anos após o tombamento, o forte passou por mais uma obra de restauro, com projeto do arquiteto Luís Saia. Este restauro provocou a descaracterização do forte, com a inclusão de elementos que nunca haviam existido neste local, de acordo com os documentos históricos (MORI et al. 2003). Em 1998 e 2007 as instalações do forte foram restauradas pelo Atelier Artístico Sarasá, retomando algumas características originais.

Atualmente o Forte São João, administrado pela Secretaria de Turismo de Bertioga, é um dos melhores exemplos de utilização com fins turísti$\cos$ da região e uma das principais atrações turísticas de Bertioga, inclusive aparecendo nas placas de rua (Figura 5). A única parte da construção remanescente do século XVI é uma parede, porém essa informação não é repassada para o visitante, podendo induzi-lo a uma visão errônea da história deste forte. Seria ideal explicitar onde foram realizadas reconstruções e restauros, como se encontrava o objeto antes das obras, e quais modificações foram efetuadas. 

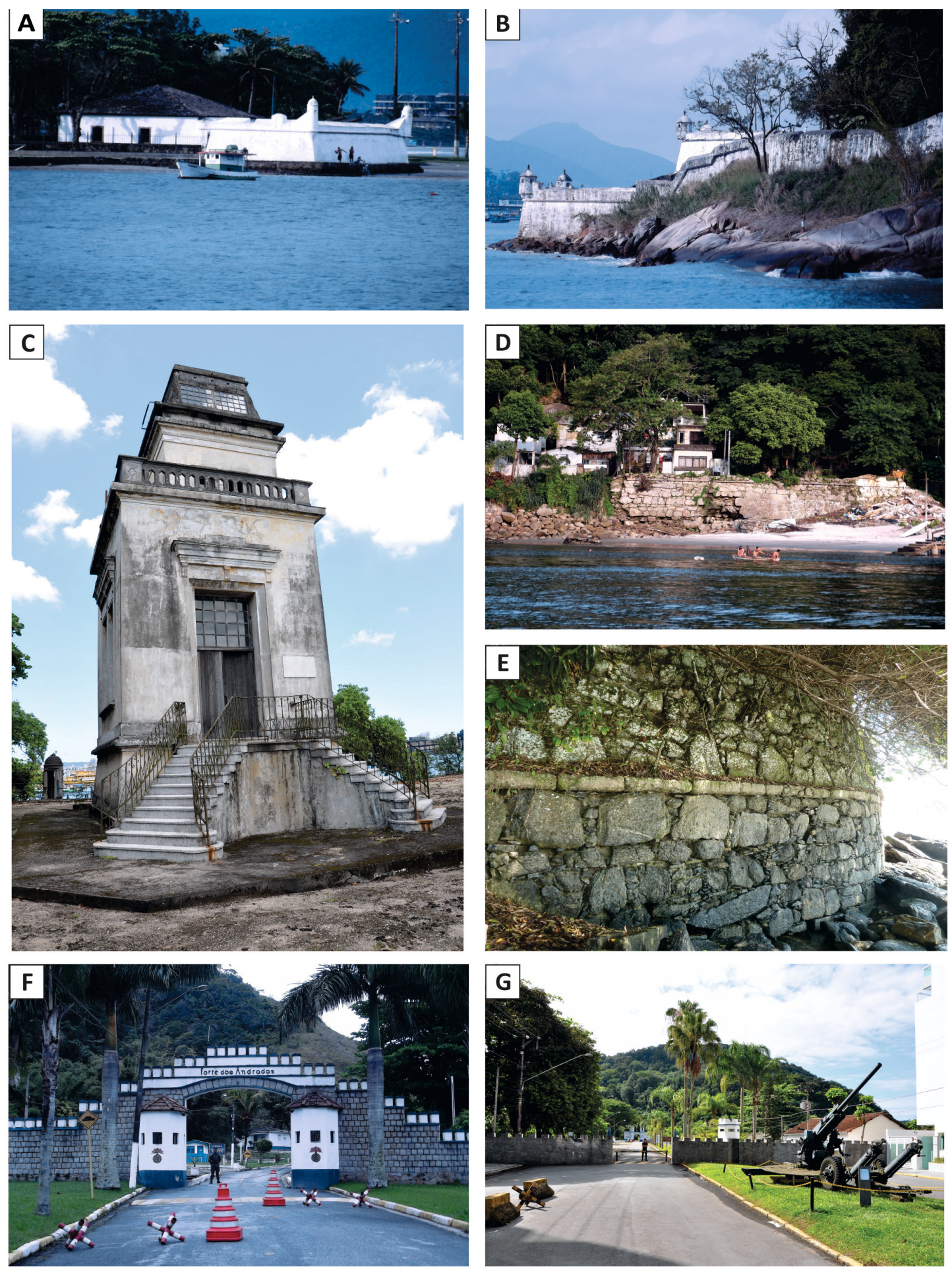

FIGURA 4 - Fortificações no litoral do estado de São Paulo. A - Forte São João. B - Fortaleza de Santo Amaro da Barra Grande. C - Fortaleza Vera Cruz de Itapema. D - Fortim da Praia do Góes. E - Forte São Luiz. F - Forte dos Andradas. G - Fortaleza de Itaipu. Fotografias C e G: Lauro K. Dehira. 


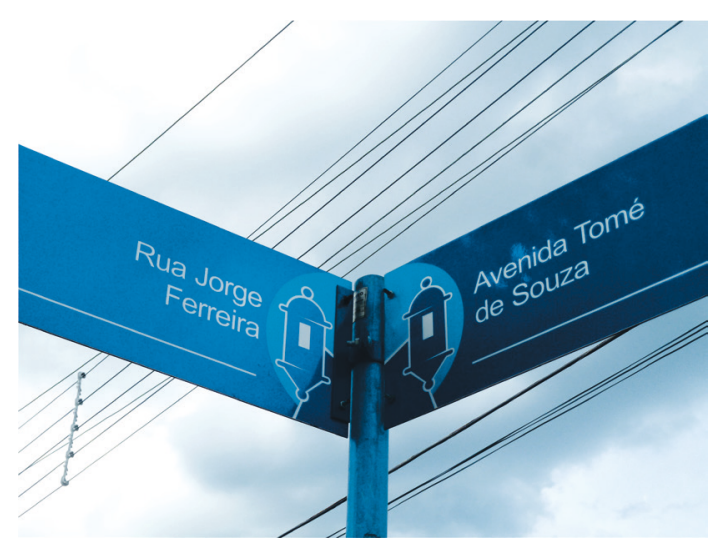

FIGURA 5 - Placas de rua no município de Bertioga, com o símbolo do Forte São João, mostrando a sua importância para o município.
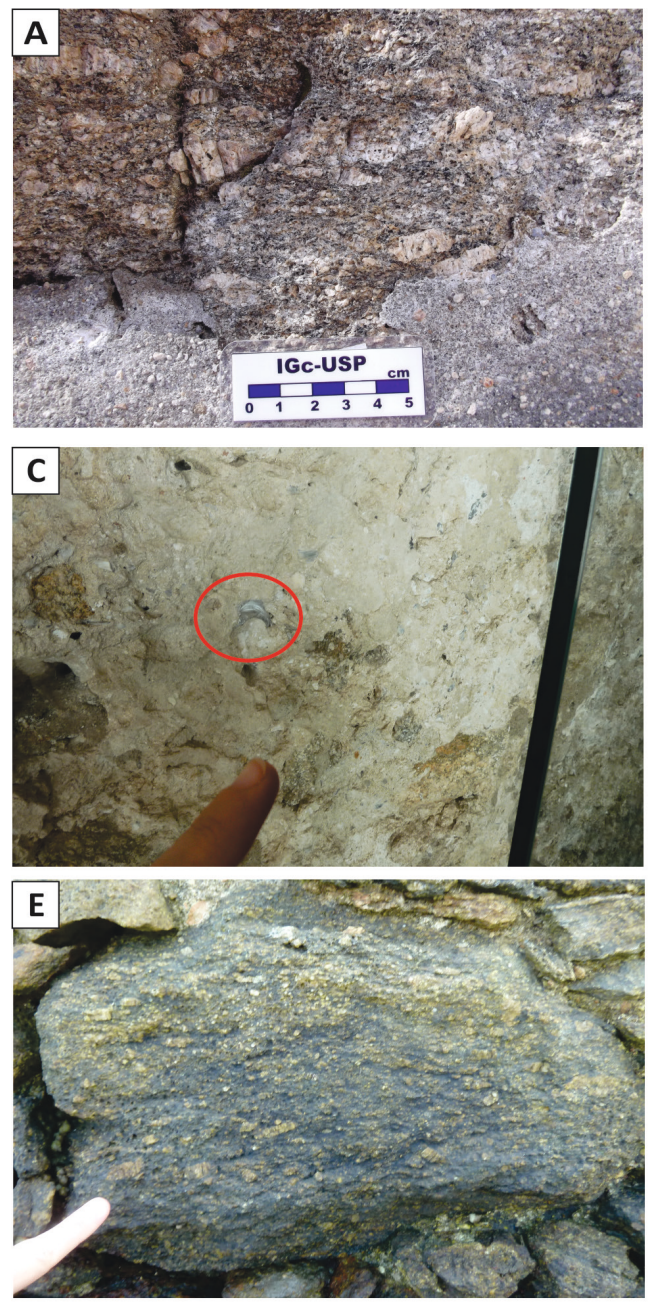

\section{Aspectos geológicos}

O forte foi edificado essencialmente com blocos de pedra e argamassa. Todavia, parte dessa construção foi coberta com cimento e as paredes foram caiadas em uma das obras de restauro.

Atualmente, pouco resta da construção original feita essencialmente de rocha, apenas a escada que dá acesso à plataforma das armas (Figura 6A), parte de uma das paredes (remanescente do século XVI) (Figuras 6B e C), dois parapeitos de janelas e um batente de porta (Figura 6D). O forte está construído sobre uma plataforma de blocos predominantemente de gnaisse milonítico porfiroblástico (Figura 6E), com cristais tabulares a amendoados de feldspato potássico rosado, podendo alcançar
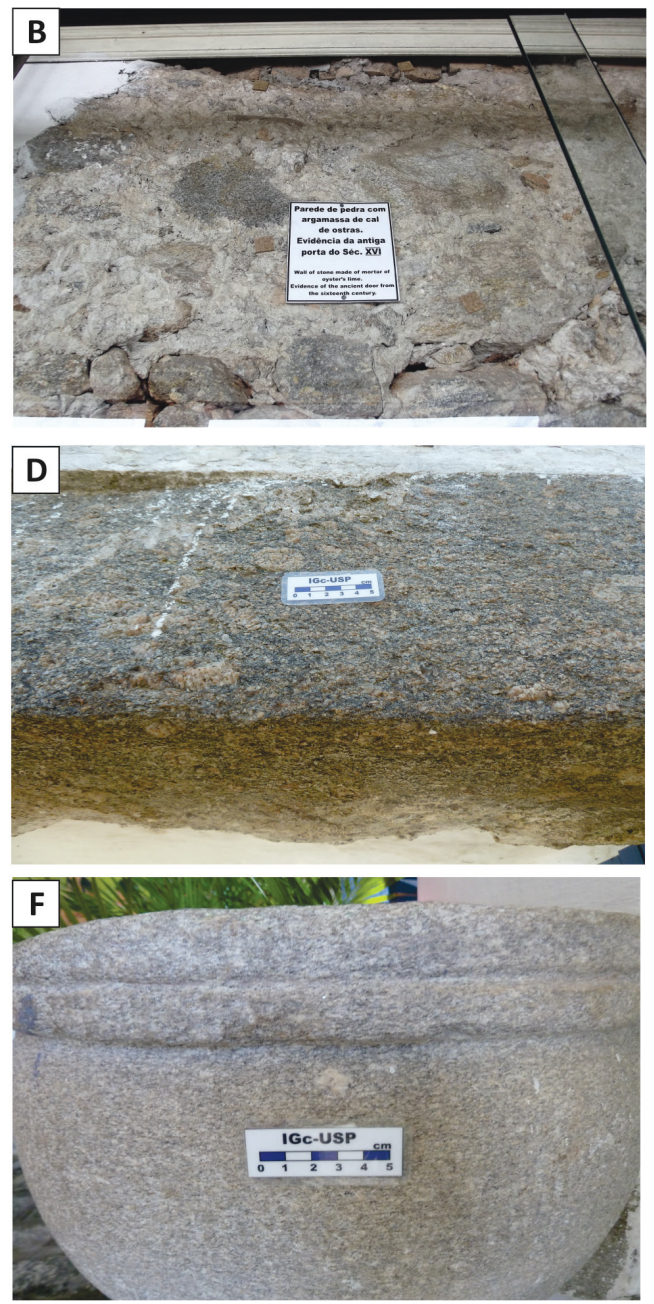

FIGURA 6 - Forte São João. A - Detalhe do degrau da escada feito em gnaisse milonítico porfiroblástico. B - Parede do século XVI feita com gnaisse milonítico porfiroblástico. C - Detalhe da presença de conchas na argamassa na parede da foto B. D - Batente de porta construído com gnaisse milonítico porfiroblástico. $\mathrm{E}$ - Blocos de gnaisse milonítico porfiroblástico utilizados na plataforma do Forte. F - Pia feita em gnaisse granítico milonítico de granulação fina e coloração cinza. 
$15 \mathrm{~cm}$, sendo esta, a mesma rocha observada na construção do forte. Localmente, ocorrem blocos de granito. Esta plataforma só é visível quando a maré está baixa.

Uma pia, anterior a 1817, está exposta no forte, constituída por gnaisse granítico milonítico de granulação fina e coloração cinza (Figura 6F).

Apesar do Forte São João encontrar-se sobre a Unidade dos Depósitos Litorâneos Indiferenciados, acredita-se que os dois litotipos utilizados na construção sejam provenientes de pedreiras localizadas na região, onde afloram os gnaisses do Complexo Costeiro. Não é possível afirmar a localização da pedreira de onde os blocos foram retirados, devido à falta de documentação sobre a sua proveniência. $\mathrm{O}$ forte está localizado próximo à Unidade de Gnaisses Peraluminosos, segundo mapa de PERROTTA et al. (2005). Entretanto a mineralogia das rochas presentes na edificação não coaduna com uma associação aluminosa, não sendo observados minerais típicos desta associação, tais como, granada, cordierita e sillimanita, e sim, mineralogia típica de granitoides cálcio-alcalinos, mais similar à Unidade Ortognáissica, conforme observado em trabalhos de campo. A rocha de granulação mais fina poderia corresponder a esta unidade, afetada pela Zona de Cisalhamento Camburu (MUCIVUNA 2016).

\subsection{Município de Guarujá}

\subsubsection{Fortaleza de Santo Amaro da Barra} Grande

\section{Histórico e estado de conservação}

A Fortaleza de Santo Amaro da Barra Grande está localizada entre a praia do Góes e a praia de Santa Cruz dos Navegantes, na ilha de Santo Amaro, município de Guarujá (Figura 4B). Sua construção iniciou-se durante o período da união das coroas espanhola e portuguesa, em 1584, com o projeto do arquiteto militar Giovanni Batista Antonelli (AGEM 2005), o mesmo do Forte dos Reis Magos em Natal.

A construção da fortaleza tinha dois objetivos principais: proteger o estuário de Santos de invasores e marcar simbolicamente a presença espanhola no Atlântico Sul. No século XVIII visava cruzar fogos com o Forte da Estacada, que ficava na margem oposta do estuário. Obras de modificação da fortaleza ocorreram no século XVIII, como a transformação da antiga Casa de Pólvora em capela. Em 1905 a fortaleza foi desarmada e substituída pela Fortaleza de Itaipu (MORI et al. 2003).
A fortaleza foi tombada pelo IPHAN em 1964 como representante da arquitetura militar. Contudo, somente em 1993 tiveram início as obras de recuperação dos danos causados pelo tempo e pelo vandalismo.

Assim como o Forte São João (Bertioga/SP), a fortaleza é utilizada para fins turísticos e educativos com visitação turística regular e exposição permanente, sendo administrada pela Prefeitura Municipal de Guarujá. Do mesmo modo que acontece no Forte São João, as alterações não deixam claro o que é representativo do século XVI e de outras intervenções, dando a ideia de um falso histórico local.

\section{Aspectos geológicos}

A Fortaleza de Santo Amaro da Barra Grande foi edificada sobre um maciço de biotita granito porfirítico de coloração acinzentada com fenocristais de feldspato potássico rosado dispersos numa matriz de granulação média, composta por quartzo, biotita e feldspato (Figuras 7A e 7B), e presença de enclaves de minerais máficos (Granito Guarujá-Santos). Foi construída com blocos de rocha e argamassa; a parte externa atualmente encontra-se caiada, não sendo possível identificar o tipo de rocha utilizada. As guaritas voltadas para o estuário de Santos foram construídas com gnaisse granítico milonítico cinza, de granulação fina e orientado (Figura 7C), similar à rocha constituinte da pia encontrada no Forte São João (Figura 6F).

No interior da fortaleza as paredes não foram cobertas pela cal e são formadas por blocos de granito de coloração cinza com fenocristais de feldspato potássico, unidos com argamassa e conchas (Figura 7D). Atrás da fortaleza há as ruínas da antiga Casa de Pólvora, também constituídas por biotita granito porfirítico, que atualmente estão cobertas pela colonização biológica (Figura 7E).

Os blocos de granito porfirítico utilizados na fortificação tem proveniência do próprio afloramento da base desta construção (Granito GuarujáSantos), enquanto os blocos de gnaisse granítico milonítico podem ser oriundos da Unidade Ortognáissica, afetada pela Zona de Cisalhamento Camburu.

\subsubsection{Fortaleza de Vera Cruz de Itapema}

\section{Histórico e estado de conservação}

A Fortaleza de Vera Cruz de Itapema está localizada no distrito de Vicente de Carvalho, na ilha de Santo Amaro, município de Guarujá (Figura 4C). Não há documentos que comprovem a data do início da sua construção, mas acredita-se que 

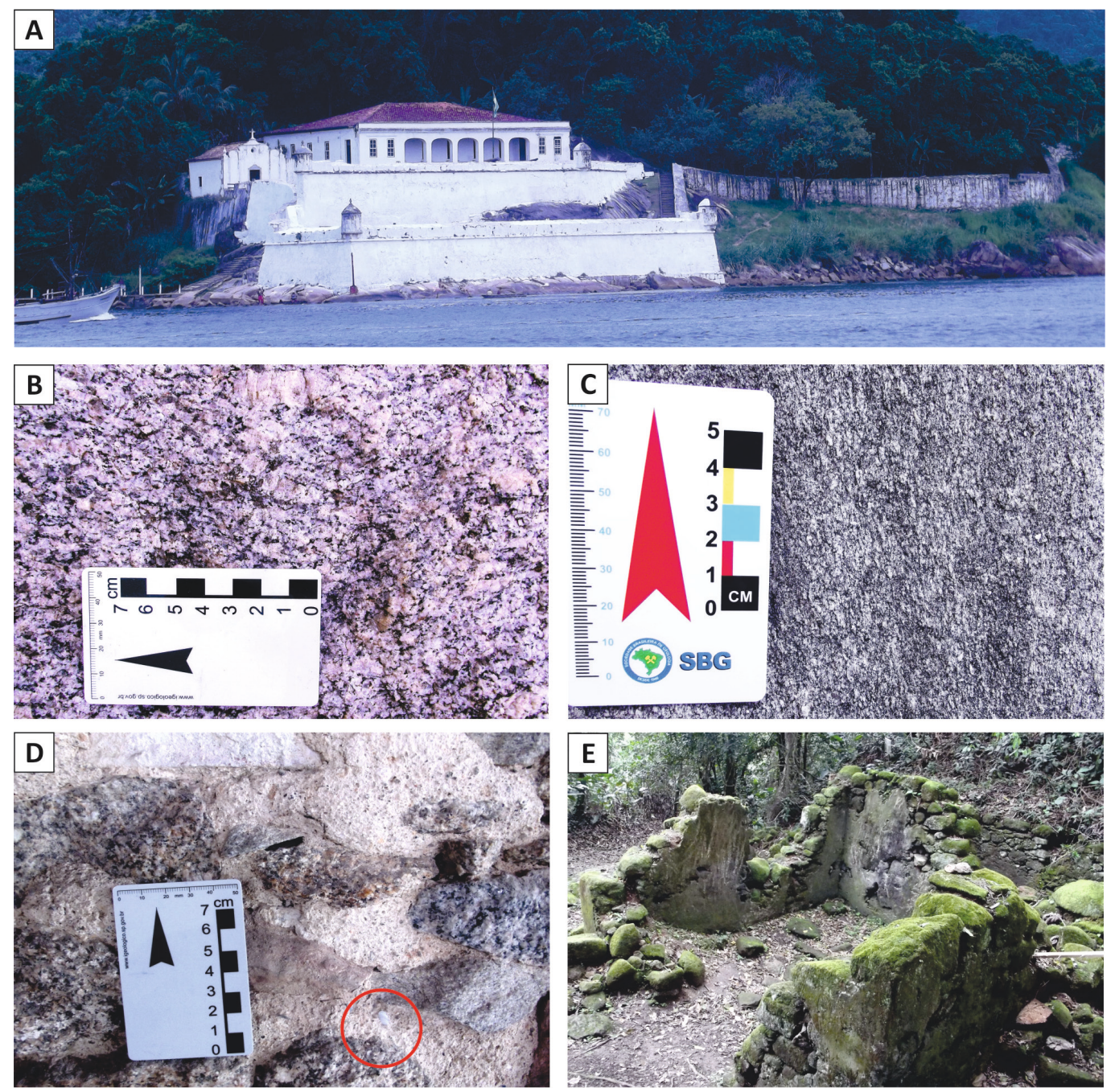

FIGURA 7 - Fortaleza de Santo Amaro da Barra Grande. A - Vista da Fortaleza construída sobre o afloramento de biotita granito porfirítico. B - Detalhe do afloramento de biotita granito porfirítico de coloração cinza. C - Detalhe do batente da guarita de gnaisse granítico milonítico cinza, de granulação fina e orientado. D Detalhe da parede feita com blocos de pedras unidos com argamassa com conchas. E - Ruínas da Casa de Pólvora coberta pela colonização biológica.

seja do final do século XVI (AGEM 2005). Assim como outras fortificações da Baixada Santista, foi construída numa cortina dupla de fortificações que pretendia cruzar fogos com o Forte de Santos.

A fortaleza foi reformada em 1860 e, em 1906, passou para a jurisdição da Alfândega de Santos. O edifício do quartel foi demolido, onde foi instalada uma torre com holofotes, porém não há informação sobre essa alteração no local, induzindo a uma interpretação de arquitetura militar (com torres) que não existiu nas fortificações do litoral paulista (MORI et al. 2003).

No ano de 1982 foi tombada pelo Conselho de Defesa do Patrimônio Histórico, Arqueológi- co, Artístico e Turístico do Estado de São Paulo (CONDEPHAAT). Atualmente é um posto de fiscalização da Alfândega de Santos. Apesar de integrar o Circuito dos Fortes, a Alfândega não permite a visitação turística.

\section{Aspectos geológicos}

A fortaleza foi construída sobre uma ocorrência de gnaisse milonítico com coloração acinzentada com feldspatos potássicos deformados (Figura 8A).

Atualmente, pouco resta da construção feita essencialmente de rocha, com exceção da escada 

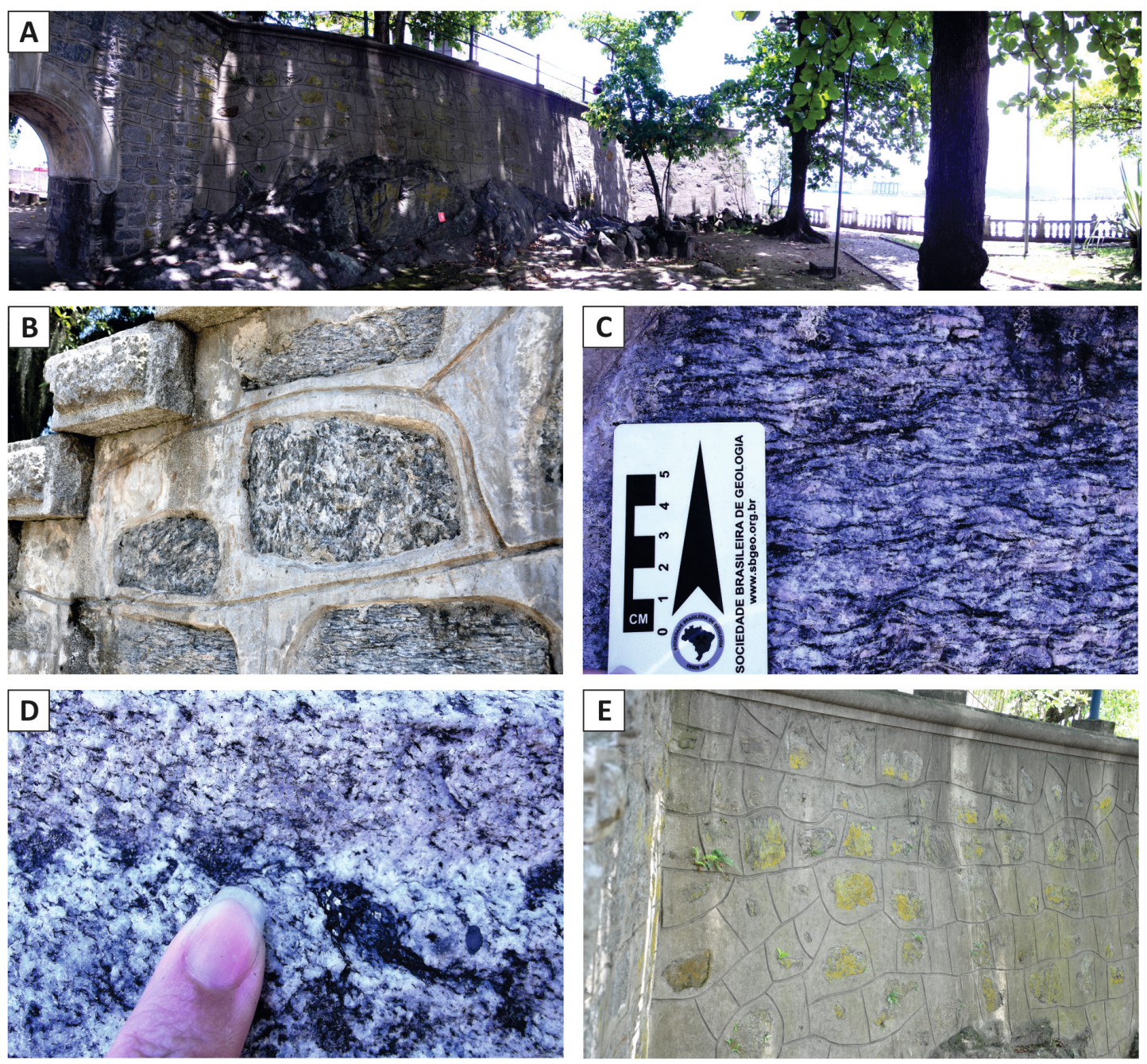

FIGURA 8 - Fortaleza Vera Cruz de Itapema. A - Vista parcial da Fortaleza construída sobre o afloramento de gnaisse milonítico com coloração acinzentada. B - Vista lateral da escada de acesso à Fortaleza de Itapema, blocos de gnaisse milonítico e degraus de biotita granito com granulação fina. C - Detalhe do gnaisse milonítico do afloramento e também utilizado na base da escada. D - Detalhe dos degraus da escada com biotita granito com granulação fina. E - Blocos com a presença de colonização biológica devido à falta de iluminação solar. Fotografias B e E: Lauro K. Dehira.

que dá acesso à parte superior da fortaleza (Figura 8B). A base da escada é feita de blocos de gnaisse milonítico (Figura 8C), enquanto os degraus, com biotita granito com granulação fina e coloração acinzentada (Figura 8D).

A Fortaleza de Vera Cruz de Itapema encontra-se sobre a Unidade dos Depósitos Litorâneos Indiferenciados. Porém, os blocos de gnaisse milonítico utilizados na sua construção têm proveniência do próprio afloramento da base desta construção. Este ponto localiza-se próximo às unidades Ortognáissica e Granito Gnáissica Migmatítica de PERROTTA et al. (2005), entretanto esta rocha está mais deformada que aquela encontrada no
Forte São João. Assim sua proveniência parece estar associada à Unidade Granito Gnáissica Migmatítica, com o desenvolvimento de foliação milonítica relacionada com a Zona de Cisalhamento do Bairro Alto.

O biotita granito encontrado nos degraus da escada não apresenta similaridades com o Granito Guarujá-Santos, que normalmente é descrito na literatura como um granito porfirítico. Existe a possibilidade de a utilização deste granito ser posterior, na época de construção da torre, podendo inclusive ser de outra região.

Os blocos que sustentam a fortaleza e a escada estão cobertos por colonização biológica, que se 
concentra onde não há incidência direta do sol, devido à presença de cobertura vegetal (Figura $8 \mathrm{E}$ ).

\subsubsection{Fortim da Praia do Góes}

\section{Histórico e estado de conservação}

O Fortim da Praia do Góes está localizado na praia homônima, na ilha de Santo Amaro, no município de Guarujá (Figura 4D). Sua construção data de 1767, realizada por Morgado de Matheus, e visava impedir desembarques de invasores na praia ao lado da Fortaleza de Santo Amaro da Barra Grande (MORI et al. 2003).

O fortim foi tombado em 1964 junto com a Fortaleza de Santo Amaro da Barra Grande e atualmente não há qualquer uso turístico e/ou educativo, uma vez que se encontra em ruínas e bastante modificado pelo acréscimo de materiais novos, como restos de cimento e de tijolos de antigas construções ao lado do muro externo (Figura 9C).

Além disso, suas ruínas estão descaracterizadas e deterioradas por conta da ocupação irregular presente sobre a antiga plataforma de armas e ao lado do muro (Figura 9D).
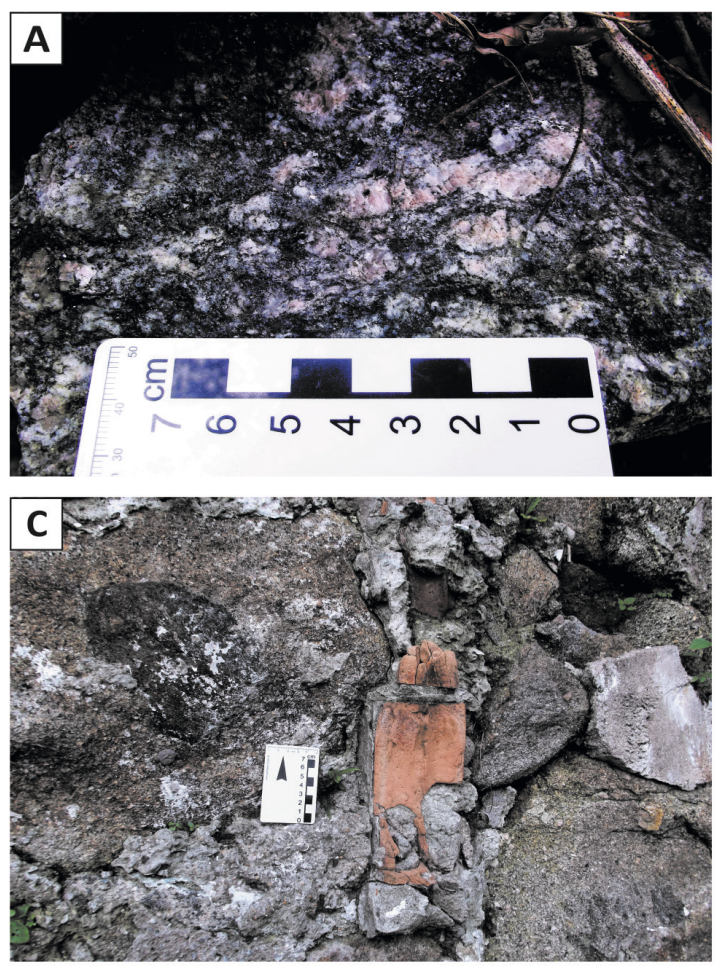

\section{Aspectos geológicos}

O fortim foi construído com blocos de biotita granito porfirítico de coloração cinza com fenocristais de feldspato potássico rosado dispersos numa matriz de granulação média, composta por quartzo, biotita e feldspato (Figura 9A); os blocos foram unidos com argamassa e conchas (Figura 9B).

Os blocos utilizados na sua construção têm provável proveniência do afloramento onde está edificada a Fortaleza de Santo Amaro da Barra Grande (a cerca de 1 km de distância), ou de afloramentos próximos, associados ao Granito GuarujáSantos, em função da similaridade litológica.

\subsubsection{Forte São Luiz}

\section{Histórico e estado de conservação}

O Forte São Luiz está localizado na ponta da Baleia, na ilha de Santo Amaro, município de Guarujá (Figura 4E). A construção do forte iniciou-se em 1770, próximo ao antigo Forte São Felipe, abandonado no século XVII (MORI et al. 2003). A construção desse forte tinha por objetivo cruzar
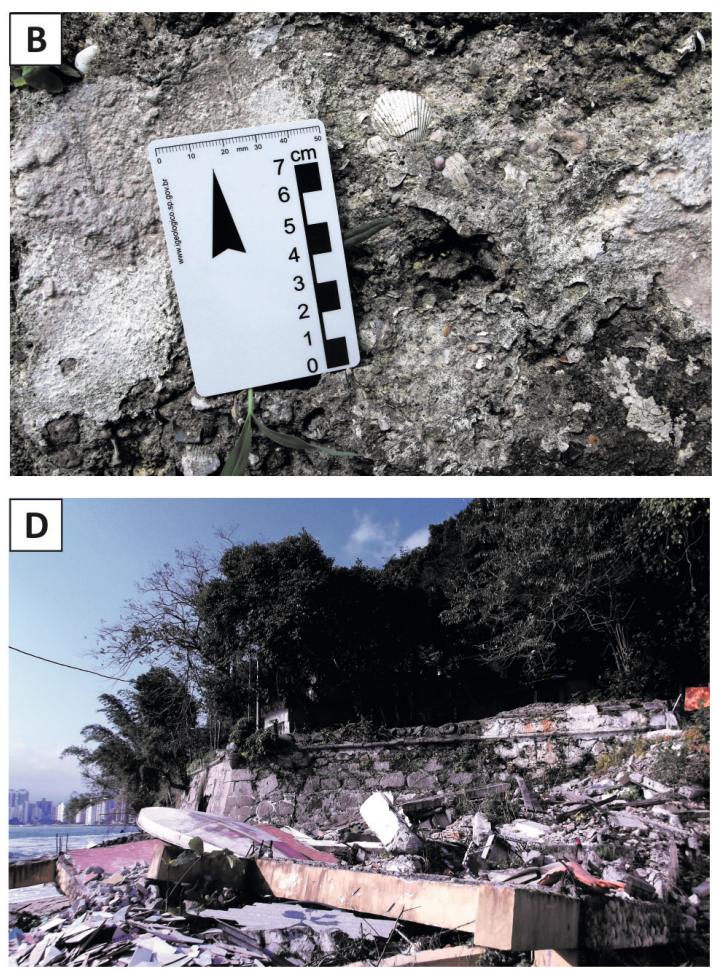

FIGURA 9 - Fortim da Praia do Góes. A - Bloco de biotita granito porfirítico de coloração cinza utilizado no muro da fortificação. B - Detalhe da argamassa com conchas. C - Materiais de construção contemporâneos acrescentados ao muro da fortificação. D - Vista das ruínas do fortim com construções posteriores demolidas sobre seus alicerces. 
fogos com o Forte São João através de uma cortina dupla de fortificações para proteger a entrada do Canal de Bertioga.

Em meados do século XVI o artilheiro alemão Hans Staden foi aprisionado pelos índios Tupinambás no local onde era o antigo Forte São Felipe (STADEN 1974).

O forte foi tombado pelo IPHAN em 1965 e atualmente restam apenas ruínas do forte que estão tomadas pela vegetação, prejudicando sua estrutura. Apesar de fazer parte do Circuito dos Fortes, não possui infraestrutura mínima para receber turistas.

\section{Aspectos geológicos}

O forte foi construído com blocos de gnaisse milonítico porfiroblástico com porfiroblastos de feldspato potássico de coloração bege (Figura $10 \mathrm{~A}$ ), rocha idêntica à encontrada no Forte São João, localmente com veios de quartzo e presença de colonização biológica.

Atualmente, não é mais possível observar a argamassa utilizada para unir os blocos (Figura 10B). O forte encontra-se em ruínas e está coberto por vegetação, dificultando a observação da área total que ocupava (Figuras 10C e D).

Os afloramentos próximos a este forte foram descritos como um milonito-gnaisse porfiroblástico fortemente tectonizado e orientado, originado a partir de granitos porfiroblásticos (SILVA et al. 1977). Assim como considerado para o Forte São João, estas rochas apresentam maior similaridade com as rochas pertencentes à Unidade Ortognáissica.

\subsubsection{Forte dos Andradas}

\section{Histórico e estado de conservação}

O Forte dos Andradas, também conhecido como Forte do Monduba, está localizado no morro homônimo, ilha de Santo Amaro, no município de Guarujá (Figura 4F). Foi projetado pelo Tenente Coronel de engenharia João Luiz Monteiro e é considerada a última e mais moderna fortificação brasileira (BARRETO 1958). Sua construção iniciou-se em 1938 e atualmente é utilizado como quartel administrativo do Exército Brasileiro.
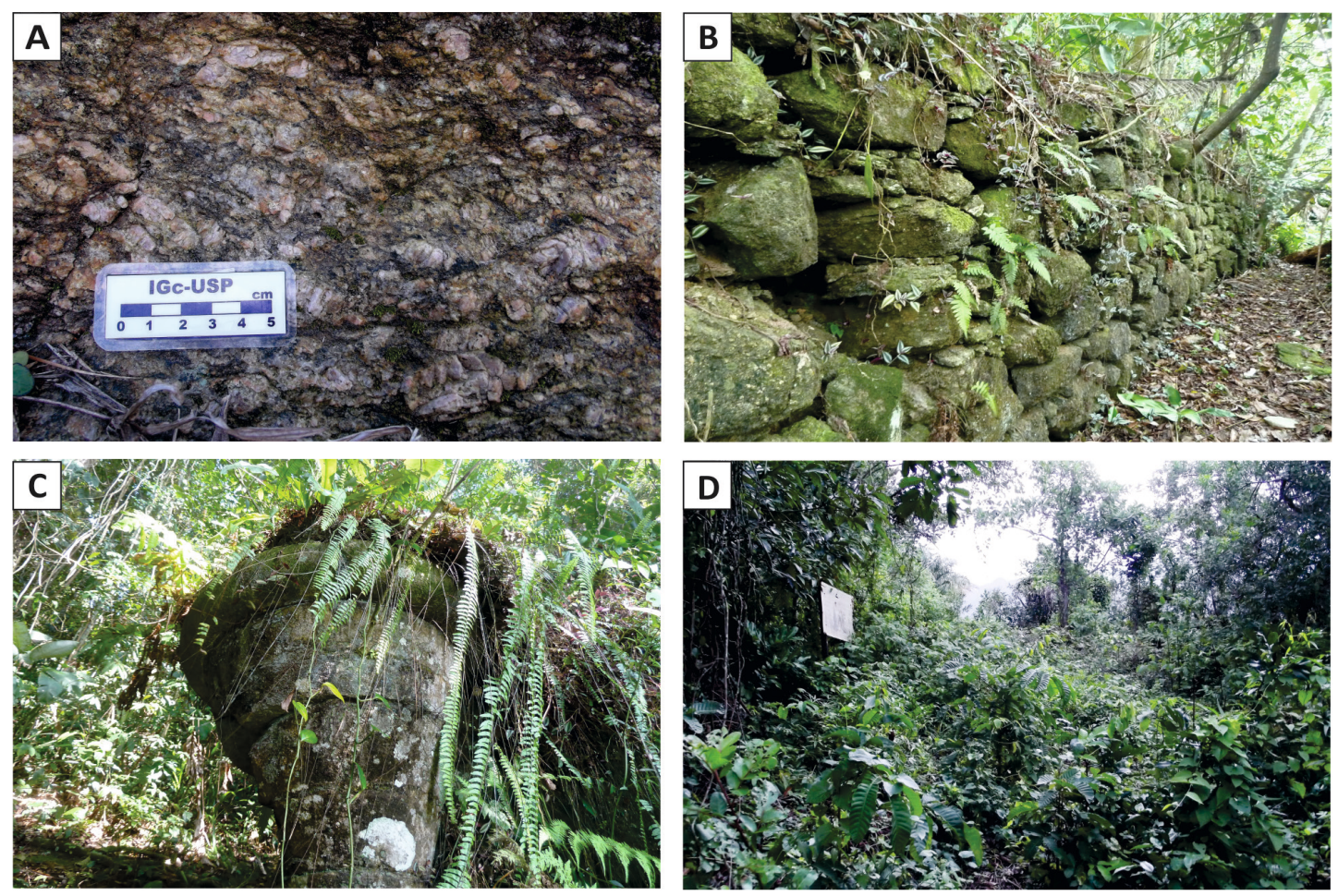

FIGURA 10 - Forte São Luiz. A - Gnaisse milonítico porfiroblástico com porfiroblastos de feldspato potássico de coloração bege utilizado na construção do forte. B - Blocos utilizados na parede do forte sem a presença da argamassa utilizada na construção. C - Ruínas do forte coberta por colonização biológica. D - Interior do forte coberto pela vegetação. 
O forte é constituído por um complexo sistema de túneis encravado em rochas, que visava proteger o acesso ao porto de Santos. Foi construído numa cortina dupla de fortificações que tinha por objetivo cruzar fogos com a Fortaleza de Itaipu no município de Praia Grande.

O Forte possui instalações boas e conservadas e faz parte do Circuito dos Fortes, porém, atualmente o Exército Brasileiro não permite a sua visitação turística, que esteve aberta entre os anos de 1994 e 2002.

\section{Aspectos geológicos}

O Forte dos Andradas foi edificado em grande parte em concreto; somente os túneis que dão acesso ao forte foram feitos com blocos de granito de granulação fina e coloração cinza, composto por quartzo, biotita e feldspato potássico (Figuras 11A e B). Os blocos utilizados em sua construção têm proveniência do próprio morro onde está edificado o forte, onde aflora o Granito Guarujá-Santos. Trata-se de uma fácies não porfirítica deste granito, conforme já descrito por SILVA et al. (1977).
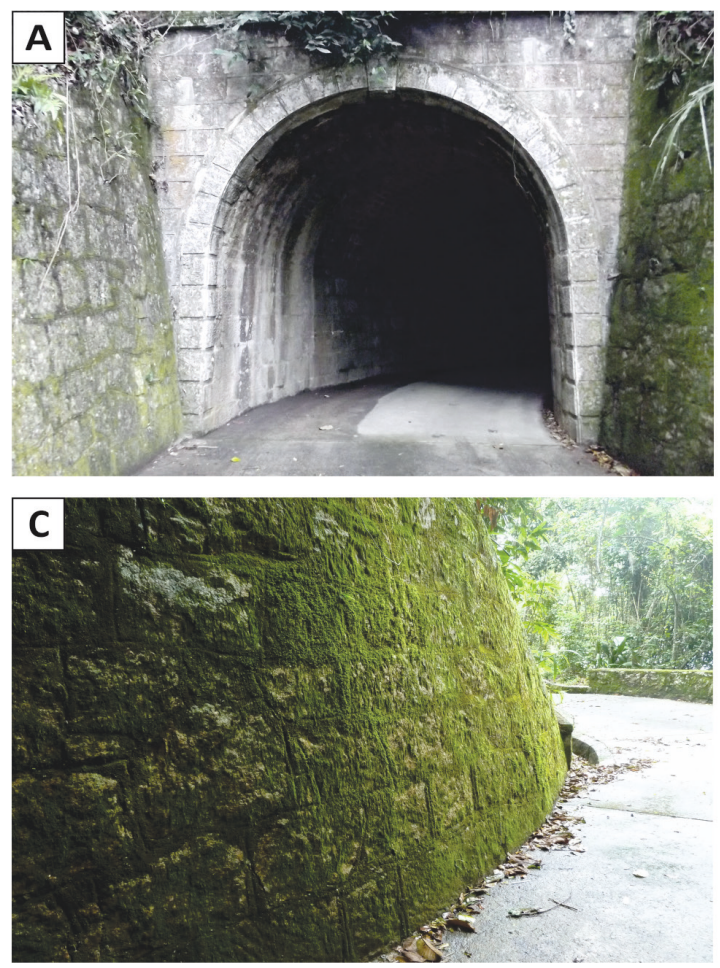

Os blocos de rochas localizados na estrada de acesso ao forte estão cobertos por colonização biológica, devido à não incidência direta do sol por conta da presença de cobertura vegetal (Figura 11C). Nos locais onde ocorre iluminação solar direta, a colonização biológica concentra-se principalmente na argamassa que assenta os blocos (Figura 11D).

\subsection{Município de Praia Grande}

\subsubsection{Fortaleza de Itaipu}

\section{Histórico e estado de conservação}

A Fortaleza de Itaipu está localizada na ponta homônima, no município de Praia Grande (Figura 4G). Sua construção data de 1902, com a finalidade de defender o Porto de Santos em substituição à Fortaleza de Santo Amaro da Barra Grande (MORI et al. 2003). Foi construída numa cortina dupla de fortificações que tinha por objetivo cruzar fogos com o Forte dos Andradas no município de Guarujá (Figuras 4F, 11).
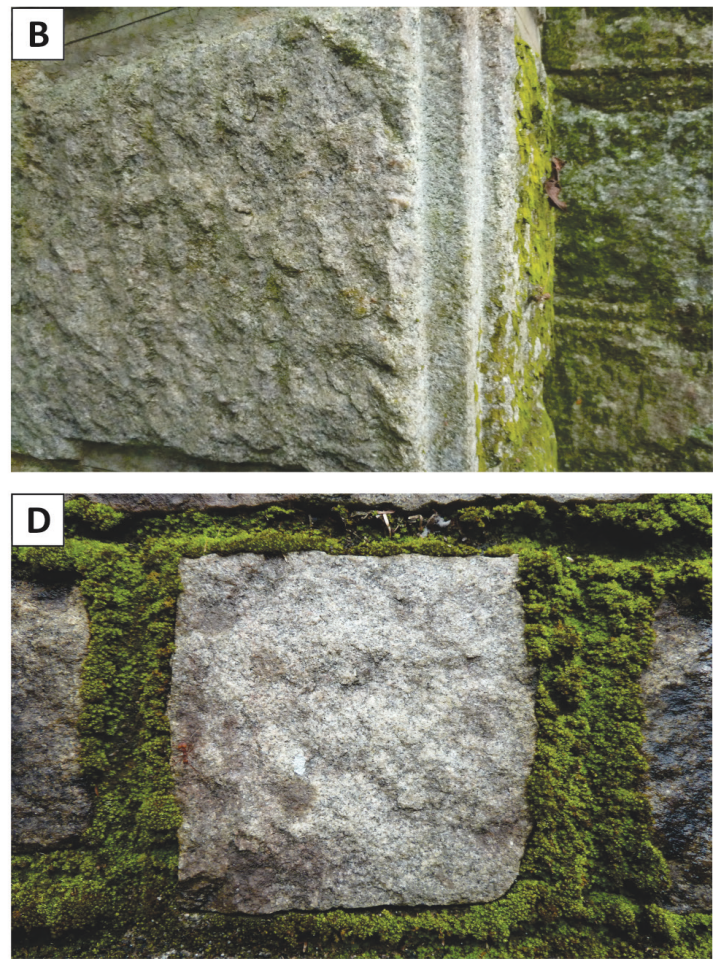

FIGURA 11 - Forte dos Andradas. A - Entrada do túnel, por ser um local menos úmido, não há colonização biológica. B - Detalhe do bloco utilizado para construção do túnel - granito com granulação fina e coloração cinza. C - Muro coberto pela colonização biológica, devido à falta de iluminação solar. D - Colonização biológica presente somente na argamassa. 
Nesta fortaleza existem três baterias de fortificações: Forte Duque de Caxias, Forte Jurubatuba e Forte General Rego Barros; a visitação é autorizada somente à primeira. Foram construídas próximas, com o objetivo de executar a defesa terrestre e proteger das possíveis invasões.

A fortaleza possui boas condições estruturais e de divulgação ao público, e atualmente, ainda é utilizada com fins de defesa do território pelo Exército Brasileiro.

\section{Aspectos geológicos}

Trata-se de uma construção do século XX, feita em concreto, com uso de rocha apenas na escada que dá acesso ao forte (Figura 12A), representada por granito de granulação fina e coloração acinzentada (Figura 12B).

Apesar da Fortaleza de Itaipu estar sobre rochas da Unidade dos Gnaisses Bandados, não se observou litotipos dessa unidade em sua construção, mas de uma rocha similar à encontrada na Fortaleza de Vera Cruz de Itapema. Como não há

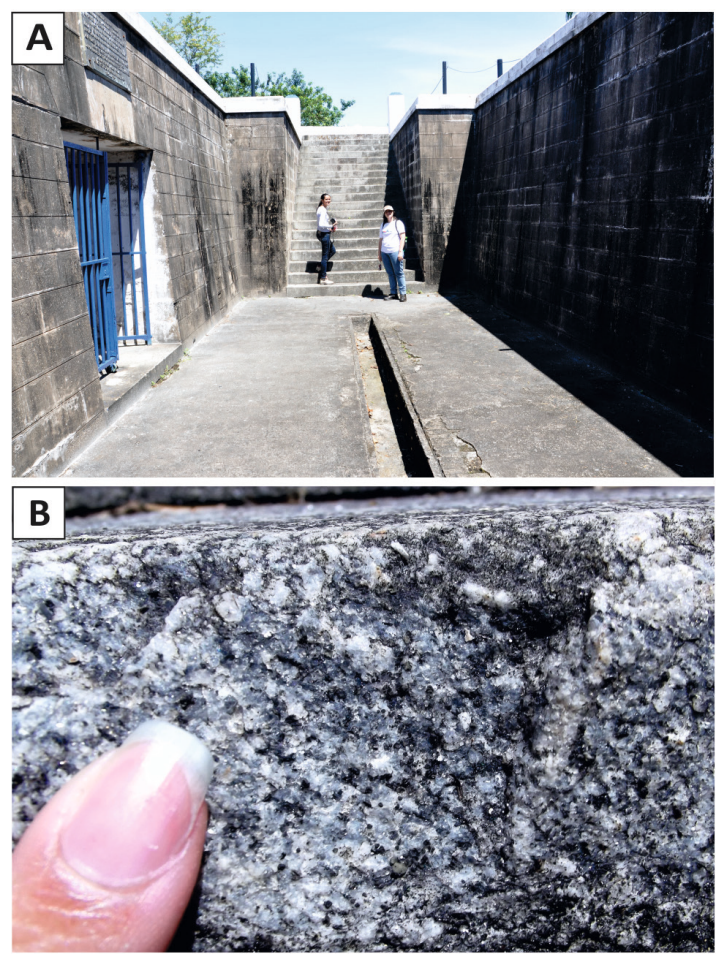

FIGURA 12 - Fortaleza de Itaipu. A - Vista da escada de acesso à fortaleza construída com granito de granulação fina e coloração acinzentada. B - Detalhe do degrau da escada feito em granito de granulação fina de coloração acinzentada. Fotografia A: Lauro K. Dehira. documentação sobre a proveniência dos blocos utilizados nessa construção e uma vez que esta fortaleza tem idade bem mais recente, é possível que o granito utilizado seja proveniente de outras localidades, devido à facilidade de transporte no século XX.

\section{CONCLUSÕES}

Os tipos de rocha predominantes nas construções das fortificações do litoral paulista são os granitos e gnaisses do Terreno Serra do Mar. Conforme o Mapa Geológico do Estado de São Paulo (PERROTTA et al. 2005), três fortificações foram edificadas sobre o Granito Guarujá-Santos, duas nos Depósitos Litorâneos Indiferenciados, uma na Unidade de Gnaisses Bandados e, uma sobre a Unidade de Gnaisses Peraluminosos.

Apesar da localização geográfica, as rochas encontradas nas fortificações nem sempre coincidem com a descrição das unidades mapeadas, a exemplo do Forte São João e da Fortaleza de Vera Cruz de Itapema (Unidade dos Depósitos Litorâneos Indiferenciados), cujas rochas são provenientes das unidades Ortognáissica e Granito Gnáissica Migmatítica, respectivamente. Embora o Forte São Luiz esteja sobre a Unidade dos Gnaisses Peraluminosos, as rochas utilizadas em sua construção, bem como os afloramentos próximos, possuem características da Unidade Ortognáissica. A Fortaleza de Santo Amaro da Barra Grande encontrase sobre o Granito Guarujá-Santos, mas também possui rochas oriundas da Unidade Ortognáissica, possivelmente afetada pela Zona de Cisalhamento Camburu.

Não há documentação histórica que comprove a origem das rochas, no entanto, ela pode ser inferida com base na similaridade e proximidade com as unidades geológicas que afloram na região. Na Fortaleza de Itaipu e em parte da Fortaleza de Vera Cruz de Itapema, os blocos de rocha utilizados na construção diferem dos afloramentos próximos, indicando outras procedências. No caso da Fortaleza de Itaipu, construída no século XX, os blocos já poderiam ser facilmente transportados; em Vera Cruz de Itapema, houve intervenções nas estruturas da fortaleza, com adição de materiais.

A pesquisa ora realizada mostra que, com base no estado de conservação, as fortificações que precisam de mais atenção são o Forte São Luiz e o Fortim da Praia do Góes, ambas no município de Guarujá. Apesar de tombadas pelo IPHAN, estão em ruínas e são candidatas ao desaparecimento. 
Destaca-se que a maior parte das fortificações do litoral paulista encontra-se no município de Guarujá. Enquanto a Fortaleza de Santo Amaro da Barra Grande é utilizada como objeto de promoção para o turismo na região, o Fortim da Praia do Góes, localizado a menos de um quilômetro, encontra-se em ruínas e em estado de deterioração por conta da ocupação irregular, da mesma forma que o Forte São Luiz. Isso decorre do fato que a população do entorno dessas fortificações não possui identidade com o patrimônio cultural e muitas vezes desconhece a importância desses monumentos no contexto histórico.

A tentativa de divulgar as fortificações do litoral paulista ocorreu com a elaboração do projeto Circuito dos Fortes em 2004 (AGEM 2005), porém apesar de ter sido criado, não foi implantada a infraestrutura adequada para a divulgação e sua concretização.

Com o presente trabalho, espera-se que os órgãos responsáveis pela administração das fortificações sejam sensibilizados em relação à sua conservação e divulgação. Almeja-se que essas ações modifiquem a atual situação das fortificações, relegadas ao esquecimento, bem como valorizem os aspectos geológicos e históricos, de modo a salvaguardar os registros destas fortificações, que outrora foram de extrema importância para a consolidação e proteção do território paulista. Os resultados aqui apresentados também podem ser utilizados como subsídio para elaboração de roteiros geoturísticos.

\section{AGRADECIMENTOS}

Os resultados deste trabalho são parte da Dissertação de Mestrado da primeira autora. As autoras agradecem o apoio da Pró-Reitoria de Pesquisa da Universidade de São Paulo, por meio do Programa de Incentivo à Pesquisa, que permitiu a criação do Núcleo de Apoio à Pesquisa em Patrimônio Geológico e Geoturismo (GeoHereditas), do Conselho Nacional de Desenvolvimento Científico e Tecnológico (CNPq), pela bolsa de mestrado (Processo 134376/2014-5) e da Fundação de Amparo à Pesquisa do Estado de São Paulo (FAPESP) - Processo 2011/17261-6.

\section{REFERÊNCIAS BIBLIOGRÁFICAS}

AGEM - AGÊNCIA METROPOLITANA DA BAIXADA SANTISTA. 2005. Guia Circuito dos fortes: da costa da mata atlântica. Dispo- nível em http://www.agem.sp.gov.br/midia/ guia-circuito-dos-fortes.pdf. Acessado em 20 out. 2014.

ALMEIDA, F.F.M.; HASUI, Y.; BRITO NEVES, B.B.; FUCK, R.A. 1977. Províncias estruturais brasileiras. In: SBG, SIMPÓSIO DE GEOLOGIA DO NORDESTE, 8, Campina Grande, Boletim Especial, 1: 12-13.

ALMEIDA, F.F.M.; HASUI, Y.; BRITO NEVES, B.B.; FUCK, R.A. 1981. Brazilian structural provinces: an introduction. Earth-Science Reviews, 17(1/2): 1-29.

AZEVEDO SOBRINHO, J.M.; JANASI, V.A.; SIMONETTI, A.; HEAMAN, L.R.; SANTORO, J.; DINIZ, H.N. 2011. The Ilha Anchieta Quartz Monzonite: the southernmost expression of ca. 500 Ma postcollisional magmatism in the Ribeira Belt. Anais da Academia Brasileira de Ciências, 83(3): 891-906.

BARRETO, A. 1958. Fortificações do Brasil: resumo histórico. Editora Biblioteca do Exército, Rio de Janeiro, 337 p.

CAMARGO, P.F.B. 2002. Arqueologia das fortificações oitocentistas da planície costeira Cananeia/Iguape, SP. Museu de Arqueologia e Etnologia, Universidade de São Paulo, São Paulo, Dissertação de Mestrado, 190 p.

CASTRO, A.H.F. 2009. Muralhas de pedra, canhões de bronze, homens de ferro: fortificações no Brasil de 1504 a 2006. Fundação Cultural do Exército Brasileiro, Rio de Janeiro, $478 \mathrm{p}$.

CASTRO, C.E. 2010. História de Bertioga. In: UFSC, SEMINÁRIO REGIONAL DE CIDADES FORTIFICADAS E PRIMEIRO ENCONTRO TÉCNICO DE GESTORES DE FORTIFICAÇÕES, 6. Florianópolis, Anais, 1: $1-9$.

CUNHA, E. 1904. Os reparos nos fortes de Bertioga. In: C. Afrânio (ed.) Obra completa organizada sob a direção de Afrânio Coutinho. Rio de Janeiro, José Aguilar, p. 677-680.

DIAS NETO, C.M. 2001. Evolução tecno-termal do Complexo Costeiro (Faixa de dobramentos Ribeira) em São Paulo. Instituto de Geociências, Universidade de São Paulo, São Paulo, Tese de Doutorado, $160 \mathrm{p}$. 
HEILBRON, M.; PEDROSA-SOARES, A.C.; CAMPOS NETO, M.C.; SILVA, L.C.; TROUW, R.A.J.; JANASI, V.A. 2004. Província Mantiqueira. In: V. MantessoNeto; A. Bartorelli; C.D.R. Carneiro; B.B. Brito-Neves (Org.) - Geologia do Continente Sul-Americano - Evolução da Obra de Fernando Flávio Marques de Almeida, Ed. Beca, p. 203-234.

JANASI, V.A.; VASCONCELLOS, A.C.B.C.; SIGA JÚNIOR, O.; SATO, K.; MACHADO, F.B.; MARTINS, L.; GARCIA, M.G.M. 2015. In situ U-Pb dating and Hf isotope geochemistry of zircons from granites of the Costeiro Domain, SE Brazil: timing and source contrasts with neighboring terranes of the Ribeira Belt. In: SBG, HUTTON SYMPOSIUM ON GRANITES AND RELATED ROCKS, 8, Florianopolis, Anais, 1: 69 .

KLINTOWITZ, J.B. 1983. Fortalezas históricas do Brasil. Rhodia, São Paulo, 160 p.

LICCARDO, A. 2010. La pietra e l'uomo: cantaria e entalhe em Curitiba. Editora Beca, São Paulo, 156 p.

MAFFRA, C.Q.T. 2000. Geologia estrutural do embasamento cristalino da região de São Sebastião, SP: evidências de um domínio transpressivo. Instituto de Geociências, Universidade de São Paulo, Dissertação de Mestrado, $113 \mathrm{p}$.

MANSUR, K.L; CARVALHO, I.S; DELPHIM, C.F.M.; BARROSO, E.V. 2008. O Gnaisse Facoidal: a mais carioca das rochas. Anuário do Instituto de Geociências da UFRJ, 31(2): 9-22.

MORI, V.H.; LEMOS, C.A.C.; CASTRO, A.H.F. 2003. Arquitetura militar: um panorama histórico a partir do porto de Santos. Imprensa Oficial do Estado: Fundação Cultural do Exército Brasileiro, São Paulo, 231 p.

MUCIVUNA, V.C. 2016. Estratégias de geoconservação aplicadas à geodiversidade do município de Bertioga - SP e às fortificações do litoral paulista. Instituto de Geociências, Universidade de São Paulo, Dissertação de Mestrado, $142 \mathrm{p}$.

NAKAMUTA, A.S. 2009. Forte São João e o Patrimônio Histórico e Artístico Nacional. Escola de Engenharia de São Carlos, Universidade de São Paulo, São Carlos, Dissertação de Mestrado, $152 \mathrm{p}$.

OLIVEIRA, M.M. 2004. As fortificações portuguesas de Salvador quando Cabeça do Brasil. Fundação Gregório de Mattos, Salvador, $258 \mathrm{p}$.

PARDAL, P. 1999. Desfazendo lendas: uma troca de plantas arquiteturais, telhas e coxas de escravas, óleo de baleia nas argamassas. Revista do Instituto Histórico e Geográfico Brasileiro, 160(402): 7-29.

PASSARELLI, C.R. 2001. Caracterização estrutural e geocronológica dos domínios tectônicos da porção sul-oriental do estado de São Paulo. Instituto de Geociências, Universidade de São Paulo, Tese de Doutorado, 254 p.

PERROTTA, M.M.; SALVADOR, E.D.; LOPES, R.C.; D'AGOSTINHO, L.Z.; PERRUFFO, N.; GOMES, S.D.; SACHS, L.L.B.; MEIRA, V.T.; GARCIA, M.G.M.; LACERDA FILHO, J.V. 2005. Mapa Geológico do Estado de São Paulo, escala 1: 750.000. Programa Geologia do Brasil, CPRM, São Paulo.

SANTIAGO, C.C. 1992. Aditivos orgânicos em argamassas antigas. Faculdade de Arquitetura e Urbanismo, Universidade Federal da Bahia, Salvador, Dissertação de Mestrado, $128 \mathrm{p}$.

SILVA, A.T.S.F.; CHIODI FILHO, C.; CHIODI, D.K.; PINHO FILHO, W.D. 1977. Projeto Santos-Iguape. Companhia de Pesquisas de Recursos Minerais, São Paulo, 2v. (Relatório final - ficha de descrição de afloramentos).

SOUZA, A.F. 1885. Fortificações no Brazil. Revista do Instituto Histórico e Geographico e etnográfico do Brasil. 48(2): 5-140.

STADEN, H. 1974 (1557). Duas viagens ao Brasil. Ed. Itatiaia e EDUSP, São Paulo, 216 p.

SUGUIO, K.; MARTIN, L. 1978. Quaternary marine formations of the state of São Paulo and southern Rio de Janeiro. In: INTERNATIONAL SYMPOSIUM ON COASTAL EVOLUTION IN THE QUATERNARY. São Paulo. Publicação Especial, 1: 1-55.

TEIXEIRA, P.R.R. 2011. Forte de São João da Bertioga. Revista da Cultura, 18: 56-67. 


\section{Endereço dos autores:}

Vanessa Costa Mucivuna, Eliane Aparecida Del Lama e Maria da Glória Motta Garcia - Núcleo de Apoio à Pesquisa em Patrimônio Geológico e Geoturismo (GeoHereditas), Instituto de Geociências, Universidade de São Paulo, Rua do Lago, 562, Butantã, CEP 05508-080, São Paulo, SP, Brasil. E-mails: vanessa. mucivuna@usp.br, edellama@usp.br,mgmgarcia@usp.br

Artigo submetido em 3 de abril de 2016, aceito em 17 de maio de 2016. 